\title{
Applications of Morphochronology to the Active Tectonics of Tibet
}

F. J. Ryerson, P. Tapponnier, R. C. Finkel, A.-S. Meriaux, J. Van der Woerd, C. Lasserre, M.-L. Chevalier, X. Xiwei, L. Haibing, G. C. P. King

January 31, 2005

In-Situ Produced Cosmogenic Nuclides and Quantification of Geological Processes, Special Paper 
This document was prepared as an account of work sponsored by an agency of the United States Government. Neither the United States Government nor the University of California nor any of their employees, makes any warranty, express or implied, or assumes any legal liability or responsibility for the accuracy, completeness, or usefulness of any information, apparatus, product, or process disclosed, or represents that its use would not infringe privately owned rights. Reference herein to any specific commercial product, process, or service by trade name, trademark, manufacturer, or otherwise, does not necessarily constitute or imply its endorsement, recommendation, or favoring by the United States Government or the University of California. The views and opinions of authors expressed herein do not necessarily state or reflect those of the United States Government or the University of California, and shall not be used for advertising or product endorsement purposes.

This work was performed under the auspices of the U.S. Department of Energy by University of California, Lawrence Livermore National Laboratory under Contract W-7405-Eng-48. 


\title{
Applications of Morphochronology to the Active Tectonics of Tibet
}

\author{
F.J. Ryerson ${ }^{1}$ \\ Paul Tapponnier ${ }^{2}$ \\ R.C. Finkel ${ }^{3}$ \\ A-S. Mériaux ${ }^{1}$ \\ Jerome Van der Woerd ${ }^{4}$ \\ C. Lasserre ${ }^{5}$ \\ M.-L. Chevalier ${ }^{2,1}$ \\ Xu Xiwei ${ }^{6}$ \\ Li Haibing $^{7}$ \\ G.C.P. King ${ }^{2}$
}

1. Institute of Geophysics and Planetary Physics, Lawrence Livermore National Laboratory, Livermore, 94550 CA, USA

2. Laboratoire de Tectonique, Mécanique de la Lithosphère, UMR7578, CNRS, Institut de Physique du Globe de Paris, 75252 Paris cedex 05, France.

3. Center for Accelerator Mass Spectrometry, Lawrence Livermore National Laboratory, Livermore, 94550 CA, USA.

4. Institut de Physique du Globe de Strasbourg, CNRS-UMR 7516, Strasbourg, France.

5. Département Terre Atmosphère Océan, École Normale Supérieure, 24, rue Lhomond, 75231 Paris cedex 05

6. Institute of Geology, China Earthquake Administration, Beijing 100029, China

7. Laboratory of Continental Dynamics, Institute of Geology, Chinese Academy of Geological Sciences, Beijing 100037, China. 
Abstract. The Himalayas and the Tibetan Plateau were formed as a result of the collision of India and Asia, and provide an excellent opportunity to study the mechanical response of the continental lithosphere to tectonic stress. Geophysicists are divided in their views on the nature of this response advocating either (1) homogeneously distributed deformation with the lithosphere deforming as a fluid continuum or (2) deformation is highly localized with the lithosphere that deforms as a system of blocks. The resolution of this issue has broad implications for understanding the tectonic response of continental lithosphere in general. Homogeneous deformation is supported by relatively low decadal, geodetic slip-rate estimates for the the Altyn Tagh and Karakorum Faults. Localized deformation is supported by high millennial, geomorphic slip-rates constrained by both cosmogenic and radiocarbon dating on these faults. Based upon the agreement of rates determined by radiocarbon and cosmogenic dating, the overall linearity of offset versus age correlations, and on the plateau-wide correlation of landscape evolution and climate history, the disparity between geomorphic and geodetic sliprate determinations is unlikely to be due to the effects of surface erosion on the cosmogenic age determinations. Similarly, based upon the consistency of slip-rates over various observation intervals, secular variations in slip-rate appear to persist no longer than 2000 years and are unlikely to provide reconciliation. Conversely, geodetic and geomorphic slip-rate estimates on the Kunlun fault, which does not have significant splays or associated thrust faults, are in good agreement, indicating that there is no fundamantal reason why these complementary geodetic and geomorphic methods should disagree. Similarly, the geodetic and geomorphic estimates of shortening rates across the northeasten edge of the plateau are in reasonable agreement, and the geomorphic rates on individual thrust faults demonstrate a significant eastward decrease in the shortening rate. This rate decrease is consistent with the transfer of slip from the Altyn Tagh Fault (ATF) to genetically-related thrust mountain building at its terminus. Rates on the ATF suggest a similar decrease in rate, but the current data set is too small to be definitive. Overall, the high, late Pleistocene-Holocene, geomorphic slip velocities on the the major strike-slip faults of Tibet, suggests that they absorb as much of India's convergence relative to Siberia as the Himalayan Main Frontal Thrust on the southern edge of the plateau.

\section{Introduction}

With the exception of the ocean basins, the Tibetan plateau is among the most prominent physiographic features on the surface of the Earth with an area equivalent to $\sim 2 / 3$ that of the conterminous United States and an average elevation of $\sim 5000 \mathrm{~m}$. Much as the study of the ocean basins helped to provide the fundamental constraints on global tectonics and the rheology 
of the oceanic lithosphere, the evolution of Tibet provides a similar opportunity to constrain the mechanical behavior of the continental lithosphere and the effects of plate tectonics within the continental regime. The ongoing Indo-Asian collision provides an opportunity to investigate the evolution of tectonic features within and around the collision zone over a period from $\sim 50-55$ million years to the present. As the current manifestation of Indo-Asian convergence, active tectonic processes form an important component of the long-term tectonic evolution of Asia. The rates of such processes, such as slip on major, active strike-slip faults or uplift along thrust systems, are critical to assessing how ongoing convergence is accommodated. If indeed "the present is the key to the past", the rates of active processes and the inferred deformation mechanisms should inform our understanding of the long-term tectonic evolution of central Asia.

One of the central debates involving the evolution of the Tibetan plateau concerns whether the deformation of the continental lithosphere is homogeneously distributed or localized along the boundaries of blocks undergoing little internal deformation. The latter is consistent with the basic tenets of plate tectonics, e.g., rigid lithospheric plates, while the former implies that the rheology of the continental and oceanic lithosphere may be fundamentally different, with the continents deforming more like fluids (Avouac and Tapponnier, 1993; England and Houseman, 1986; England and Molnar, 1997a,b; Peltzer and Saucier, 1996; Peltzer and Tapponnier, 1988). These endmemeber models make very different predictions regarding the rates of slip on the large strike-slip faults, such as the Altyn Tagh (ATF), Karakorum (KKF), Kunlun (KF) and Haiyuan Faults (HF) that define much of the boundary of the Tibetan Plateau (Fig. 1). Viewed as a byproduct of distributed deformation in the lower crust and continental lithosphere, relatively low rates of slip $(<1 \mathrm{~cm} / \mathrm{yr})$ on these bounding strike-slip faults suggest widely distributed, homogeneous deformation (Bendick et al., 2000; Chen et al., 2000; Shen et al., 2001a; Washburn et al., 2001). At the other extreme, if these represent localized lithospheric shear-zones, e.g., "lithospheric faults" equivalent to intra-continental plate boundaries, then slip-rates from 10-30 mm/yr are expected (Avouac and Tapponnier, 1992; Peltzer and Saucier, 1996; Tapponnier et al., 2001). The resolution of this issue, which has implications beyond the tectonics of Tibet, requires quantitative information, not only on the deep structure of these faults (Herquel et al., 1999; Wittlinger et al., 1998), but also on their slip rates.

The ability to measure slip-rate on active faults has been revolutionized by a number of recent technical developments. The global positioning system, GPS, is in wide use and there have been a number of GPS surveys focused on the determination of decadal slip-rates in central Asia (Banerjee and Burgmann, 2002; Bendick et al., 2000; Bilham et al., 1997; Chen et al., 2004; Chen et al., 2000; Larson et al., 1999; Shen et al., 2001b; Wallace et al., 2004; Wang et al., 2002; Zhang et al., 2004). More recently interferometric, synthetic aperture radar, InSAR, previously 
applied in imaging relatively large coseismic strains (Massonnet et al., 1993; Peltzer et al., 2001b; Peltzer et al., 1994; Peltzer and Rosen, 1995) has been applied to the interseismic regime, generating decadal slip-rate determinations (Peltzer et al., 2001a; Wright et al., 2004). Both GPS and InSAR have been applied in attempts to constrain the velocity field associated with the IndoAsian collision, and in determining slip-rates on individual faults. The third element of this revolution is the extension of rate estimates obtained by dating offset landscape features, "morphochronology", due to the more general availability of cosmic-ray exposure dating by accelerator mass spectrometry (AMS). Surface exposure dating using in-situ ${ }^{14} \mathrm{C},{ }^{10} \mathrm{Be},{ }^{26} \mathrm{Al},{ }^{21} \mathrm{Ne}$ and ${ }^{36} \mathrm{Cl}$ extends the temporal range of such determinations beyond that accessible to radiocarbon dating, as well as enabling the dating of surfaces that do not contain radiocarbon datable materials. Geodetic and geomorphic measurements should be complementary, recording fault motion over vastly different time windows. Geomorphic measurements have the advantage of integrating over many earthquake cycles, while geodetic methods are more sensitive to interseismic strain and differential motion perpendicular to the fault trace. We know of no $a$ priori reason why far-field, decadal observation interval geodetic measurements and near-field, millennial geomorphic measurements should not agree.

The application of morphochronology to active tectonic requires the preservation of tectonically offset landscape features and datable surfaces that can be used to constrain their age. In many respects, the Tibetan plateau is an ideal location for the application of cosmic-ray exposure dating. Much of the Tibetan landscape has been influenced by glacial action and late Pleistocene climate change, and locations can be found where glacial features such a moraines and glacial valleys have been tectonically offset. In other areas climate change has modulated fluvial processes resulting in the deposition of alluvial fans and in the deposition and incision of fluvial terraces. These features serve as temporal markers whose offset can be used to indicate the rate of tectonic deformation. The relatively arid climate of the plateau has allowed many of these features to be preserved, recording offsets as old as 250,000 years (Chevalier et al., 2005a). In addition, due to its high elevation, Tibet is an ideal location for the application of cosmogenic dating, as the production rates here are as high as any on the planet, allowing both smaller and younger samples to be dated with usable precision.

In this paper we will review the assumptions and methods employed in recent efforts to constrain the rates of motion along some of the major faults in Asia by cosmogenic dating, as well as addressing some of the criticisms that have been leveled at this method. We will focus on the large-scale spatial variation is millennial slip-rates across the plateau and along its boundaries, comparing these with various kinematic models of Indo-Asian deformation. Of particular interest is the variation in slip-rate along the northeastern boundary of the plateau where uplift on active 
thrusts has been linked to slip along the major strike-slip faults (Meyer et al., 1998). The genetic link between the eastward extrusion of central Tibet and uplift along the northeastern boundary prescribes and eastward decrease in strike-slip velocity that should be quantitatively reflected in uplift rates. Where possible, we will compare these rate estimates obtained by cosmogenic dating with those from (1) radiocarbon dating, (2) geodetic methods, as well as with (3) Cenozoic geologic rates.

\section{Development of Geomorphic Offsets and Cosmogenic Dating of Depositional Surfaces}

Using geomorphic offsets to determine slip-rates on active faults requires the creation of datable landscape features that are then passively preserved (Sieh and Jahns, 1984; Weldon and Sieh, 1985). The interpretational framework for determining slip-rates on strike-slip faults based on the lateral displacement of terrace risers and fluvial channels is illustrated in Figure 2. Here an alluvial surface, T3, deposited atop an active strike-slip fault is subsequently incised and a younger terrace, T2, is emplaced along the active stream. Ideally, the resulting T3/T2 riser would be continually refreshed by fluvial activity on T2. The T3/T2 riser becomes a passive offset marker only when $\mathrm{T} 2$ is abandoned due by a new episode of incision, which in turn leads to the formation of the underlying T1 terrace and the T2/T1 riser. Renewed incision indicates that the threshold between aggradation and degradation has been crossed, a condition that may be driven by climate-related variations in sediment load and/or precipitation rate. While the time at which the aggradation/degradation threshold is reached at a given point along a river may vary (Bull, 1991), terrace abandonment at a particular point should represent a discrete temporal event. The displacements recorded by terrace risers are necessarily minimum displacements, as they may be re-worked by subsequent fluvial erosion. For instance, flooding by the stream occupying T1 could cause it to temporarily reoccupy $\mathrm{T} 2$. This could result in lateral erosion of the T3/T2 riser, reducing the observed offset.

The abandonment age of a terrace is typically defined by its youngest surface exposure age and/or the radiocarbon dates obtained from the shallowest subsurface sample (cf., Mériaux et al., 2004). Coupling the abandonment of T2 with the overlying T3/T2 offset yields a maximum estimate of the slip rate, the "strath abandonment model" age (Mériaux et al., 2005), and is relevant to a scenario in which occupation of a terrace level is of short duration and no riser offset is accumulated prior to abandonment. In the case where a strath terrace has been occupied by a stream system for a period that is long relative to earthquake recurrence and some permanent riser offset is accumulated prior to abandonment, the offset should be linked with the onset of emplacement of the surface underlying the riser. This may be the case for surfaces constructed by 
high energy, ephemeral braided streams where deposition is likely diachronous. In such instances, the emplacement age can be approximated by the oldest exposure age in the surface age distribution. This "strath emplacement model" yields a minimum estimate of the slip-rate.

Both "strath" models link the age of the riser to the age of the underlying terrace, but use different extremes in the age distribution to estimate the slip-rate. An absolute lower bound on the slip rate is obtained by combining an offset with the abandonment age of the overlying terrace. This "fill-channel model" is appropriate when the strath terrace underlying the riser of interest is flooded after abandonment and buried by new "fill' deposits that yield an erroneously young age for the riser offset. However, as the riser cannot be older than the terrace into which it is incised, the abandonment age of the upper terrace yields an absolute minimum approximation of the slip rate. The appropriateness of "strath" as opposed to "fill" approximations is based upon the geomorphic characterization of the terraces in the field. The "fill" approximation is useful in determining an absolute minimum rate regardless of the nature of the terraces, and is more generally useful in determining rates from stream channel offsets, as a stream channel cannot predate the surface it incises.

Fluvial terraces can also be used to determine vertical uplift rates when a normal or thrust fault displaces active stream terraces (Figure 3, for normal faults see Avouac and Peltzer (1993)). Here tectonic activity uplifts the terraces in the hanging wall of the thrust, producing a disequilibrium stream gradient that the fluvial system seeks to eliminate by renewed incision. Continued uplift and incision can produce a series of uplifted terraces perched above an active river such as those found in the hanging walls of the Tanghenan Shan thrusts near Yanchiwan (Figure 4). Again, dating of the perched surfaces can be combined with vertical offsets and fault geometry to obtain uplift and convergence rates (cf, Hetzel et al., 2002; Hetzel et al., 2004; Van der Woerd et al., 2001). In this case the distinction between strath or fill terraces is of little consequence, and the greater vertical separation of terraces makes flooding of abandoned surfaces less likely.

\subsection{Dating depositional surfaces}

Quaternary slip-rates are almost exclusively determined by dating depositional as opposed to bedrock surfaces. Cosmic-ray exposure ages of cobbles from a single terrace often show scatter that is attributed to a number of factors including bio- and cryoturbation of the surface, postabandonment surface contamination and pre-depositional exposure or inheritance. Diachronous emplacement, characterized by a discrete time interval between the initiation of emplacement and abandonment, adds to this scatter. Interpretation of the dispersion in cosmic-ray exposure ages is difficult, and only a limited number of explicit constraints can be applied. For instance, 
comparison with radiocarbon dates from the same location has been used to help constrain the age of abandonment (Mériaux et al., 2004) though there is a priori no reason that radiocarbon dates should not also display diachroneity.

Subsurface sampling of amalgamated samples has been used to constrain pre-depositional exposure (Anderson et al., 1996; Hancock et al., 1999; Repka et al., 1997). The method makes use of the fact that the total concentration of a cosmogenic nuclide in a statistically significant sampling of cobbles will be the sum of (1) the average pre-depositional exposure inventory and (2) that accumulated locally by exposure in the surface of interest (Fig. 5). The concentration of the later component decreases exponentially with depth as production is attenuated due to shielding. Cosmogenic nuclide concentrations in totally shielded samples should reflect only the pre-depositional exposure inventory. This inherited component can then be subtracted to yield the concentration of the cosmogenic nuclide produced during exposure at the site of deposition. The concentration of a cosmogenic nuclide accumulated in a single individual cobble prior to deposition cannot be quantitatively constrained. However, depth-corrected ages from the analysis of individual subsurface cobbles does provide an upper bound on the apparent age of the surface (Fig. 5c) (cf, Mériaux et al. (2005)). Analysis of subsurface samples cannot distinguish predepositional exposure inherited during storage and transport from that may have accumulated locally due to diachronous deposition of the surface. Such information must be gleaned from the distribution of single surface cobble ages in concert with subsurface sampling and radiocarbon dating where possible. The distribution of cosmogenic ages from individual surface cobbles may be used to define upper and lower brackets on the slip rate. A depth profile, or the depthcorrected ages of single subsurface cobbles may be used to more explicitly constrain this estimate. If we assume that all the age dispersion is due to diachronous deposition - not inheritance - then the cobble ages, regardless of the interpretational model, provide the maximum age estimate or a minimum model dependent slip-rate. In Tibet, the issue is not that inheritanceeffected surface ages yield slip-rates that are too low, but rather that the geomorphic rates are high relative to geodetic measurements (Chevalier et al., 2005a; Wright et al., 2004).

\section{Geomorphic slip-rate determinations in Central Asia}

Quaternary faulting and seismicity suggest that a major portion of the active deformation in Central Asia is partitioned between strike-slip faults that rival or surpass the San Andreas Fault in length, and fold-and-thrust mountain belts (Fig. 1). Over a distance of more than $2000 \mathrm{~km}$, the Altyn Tagh Fault (ATF) forms the northern edge of the plateau, and the association of this fault with the break in topography implies a genetic link with uplift of the plateau. Along its central and eastern sections, the ATF splays into the sub-parallel Kunlun (KF) and Haiyuan Faults (HF). 
The ATF, KF and HF are all left-lateral, and are thought to guide the eastward extrusion of Tibet (Tapponnier and Molnar, 1977, 1979). Near its eastern terminus, the ATF merges with the young, fold-and-thrust ranges of the Tanghenan Shan, Taxueh Shan and Qilian Shan (Fig. 1). If these active tectonic features are related, a systematic decrease in slip-rates should be observed as slip on the ATF is partitioned onto the KF, HF and sub-perpendicular thrusts (cf., Meyer et al., 1998; $\mathrm{Xu}$ et al., 2005). Geomorphic rates using cosmogenic isotopes have been determined on the Kunlun, Altyn Tagh and Haiyuan Faults of northern Tibet, as well as the thrusts systems in the Qilian Shan and Tanghenan Shan. Here we will present a synopsis of the recent geomorphic rate determinations on these features, and evaluate the spatial variation in slip-rates with respect to existing velocity models.

If active, sinistral strike-slip faults along the northern edge of the plateau guide the eastward extrusion of Tibet, then similar dextral features must exist along the southern boundary of the plateau (Avouac and Tapponnier, 1993). Convergence along the Himalaya and eastward-directed strike-slip motion along the ATF is kinematically inconsistent with the existence of a single plate of continental lithosphere composing this entire region, and eastward motion must be accommodated along other features that decouple motion between India-Southern Tibet and northern Tibet. The Karakorum Fault (KKF), a major dextral, strike-slip fault in southwestern Tibet (Fig. 1), forms the western part of this "Tibetan plate". East of Mount Kailas, dextral motion cannot be assigned to a single well-defined tectonic feature. Rather, dextral motion has been proposed along an en echelon right-lateral shear zone, the Karakorum-Jiali Fracture Zone (KJFZ), that lies along a chord connecting the eastern and western syntaxes and transfers motion from the KKF to other faults, such as the Jiali Fault, in southeast Asia (Armijo et al., 1989). Block rheological models require that the rates of motion along the faults in southern Tibet must be comparable to those that delineate its northern boundary (cf., Avouac and Tapponnier, 1993). Quantitative rates of motion on the KKF and KJFZ are scarce relative to those in the north, and only a preliminary assessment of these models is possible or warranted at this time.

\subsection{Rates of Strike-Slip Movement in Tibet}

\subsubsection{The Kunlun Fault}

The Kunlun Fault system, is $\sim 1600 \mathrm{~km}$-long and extends between $87^{\circ} \mathrm{E}$ and $105^{\circ} \mathrm{E}$, from the high Qiangtang platform of northern Tibet, a dry permafrost plateau over $5000 \mathrm{~m}$ a.s.1., down to the humid, forested and deeply incised (2000 m a.s.l. on average) mountainous rim of Southern China's Sichuan basin (Fig. 1). On a large scale, the Kunlun Fault system follows the northeastern border of the highest part of the Tibet Plateau, and is composed of twelve principal, linear segments (Fig. 6) (Van der Woerd et al., 2000; Van der Woerd et al., 2002b; Van der Woerd et 
$a l .$, 1998). It has been one of the more historically active strike-slip faults in central Asia, and the largest earthquakes recorded this century in northern Tibet (Gu et al., 1989) ruptured segments of these sinistral faults or nearby thrusts. In particular, three large earthquakes (January 7, 1937, April 19, 1963, and March 24, 1971) ruptured the central stretch of the Kunlun Fault, with magnitudes of 7.5, 7.1 and 6.4 respectively, (e.g., Cui and Yang, 1979; Gu et al., 1989; Tapponnier and Molnar, 1977). Together, the 1963 and 1937 surface breaks were reported to reach a cumulative length of about $300 \mathrm{~km}$, with maximum horizontal displacements of 7 to $8 \mathrm{~m}$ (e.g., Li and Jia, 1981; Molnar and Lyon Caen, 1989). On November 8, 1997, the Manyi earthquake, the largest earthquake ever recorded instrumentally in northern Tibet (Ms=7.9), ruptured one of the westernmost, $\mathrm{N} 80^{\circ} \mathrm{E}$-striking segments of the Kunlun Fault, between $86^{\circ} \mathrm{E}$ and $90^{\circ} \mathrm{E}$ (Peltzer et al., 1999), a feature previously mapped on Landsat images by Tapponnier $e t$ al. (1997). The rupture length was in excess of $150 \mathrm{~km}$, and the maximum horizontal slip, $\sim 7 \mathrm{~m}$ (Peltzer et al., 1999). Then on November 14, 2001, the M-7.8 Kokoxili earthquake ruptured the Kusai Hu segment of the Kunlun Fault over a length of $\sim 300 \mathrm{~km}$ (Van der Woerd et al., 2002a).

Prior to the availability of cosmogenic dating, the average Quaternary slip-rate at the Kunlun Pass was estimated to be between 10 and $20 \mathrm{~mm} / \mathrm{yr}$ (Kidd and Molnar, 1988), and GPS results suggested a rate as small as $6 \mathrm{~mm} / \mathrm{yr}$ (Burchfiel et al., 1998) or $\sim 8-11 \mathrm{~mm} / \mathrm{yr}$ (Zhang et al., 2004). The millennial geomorphic slip-rate has been determined at 13 locations along the XidatanDongdatan, Dongxi, and Maqen segments of the fault (Fig. 6), a stretch spanning $600 \mathrm{~km}$ of the Kunlun fault system (Van der Woerd et al., 2000; Van der Woerd et al., 2002b; Van der Woerd et $a l .$, 1998). In the west, at three sites along the Xidatan-Dongdatan segment of the fault, near $94^{\circ} \mathrm{E}$, terrace riser offsets ranging from 24 to $110 \mathrm{~m}$, with cosmogenic ages ranging from $\sim 1800$ to $\sim 8200 \mathrm{yr}$, yield a mean left-lateral slip-rate of $11.7 \pm 1.5 \mathrm{~mm} / \mathrm{yr}$. At two sites along the Dongxi-Anyemaqin segment of the fault, near $99^{\circ} \mathrm{E}$, terrace riser offsets ranging from 57 to 400 $\mathrm{m}$ with ${ }^{14} \mathrm{C}$ ages ranging from 5400 to $37000 \mathrm{yr}$ B.P. yield a minimum slip-rate of $\sim 10 \mathrm{~mm} / \mathrm{yr}$, comparable to that in the west. Farther east, near $100.5^{\circ} \mathrm{E}$, along the Maqen segment of the fault, the $180 \mathrm{~m}$-offset of a lateral moraine emplaced between the last glacial maximum (20 ka) and $11,100 \mathrm{yr} \mathrm{BP}$, yields a mean slip-rate of $12.5 \pm 2.5 \mathrm{~mm} / \mathrm{yr}$. The slip-rate thus appears to be constant along the $600 \mathrm{~km}$ of the Kunlun fault studied. The average rate is $11.5 \pm 2.0 \mathrm{~mm} / \mathrm{yr}$ over the last 37,000 years (Fig. 7), and is in agreement with the higher, most recent GPS estimates (Zhang et al., 2004).

A number of important conclusions can be drawn from the Late Quaternary distribution of slip along the Kunlun Fault system. From a methodological standpoint, the same rate is obtained using either ${ }^{10} \mathrm{Be}$ or ${ }^{26} \mathrm{Al}$ cosmogenic dating of quartz or radiocarbon dating of organic material. This indicates that (1) the production rates at these elevations and latitudes are reasonably 
accurate, and (2) that the cosmogenic ages are not significantly influenced by pre-depositional inheritance or erosion. At the largest scales, the spatial constancy of the rate is consistent with the simple geometry of the fault system, which at any longitude is characterized by a single strand. Also, unlike the Altyn Tagh Fault, the Kunlun Fault does not appear to have any clear-cut spatial relationship to high-angle shortening features - large thrusts and growing mountain ranges - that characterize the northeastern edge of the plateau. Hence, the potential for slip partitioning involving other genetically-related faults is minimized. The temporal constancy of the slip-rate demonstrates that Kunlun Fault does not manifest any secular velocity variations for time periods greater than $\sim 2000$ years, the age of the youngest offset measured. Recently, based on 3D paleoseismology at Wrightwood, CA, Weldon et al. (2004) show that the slip-rate on the San Andreas Fault varied between 8.9 and $2.4 \mathrm{~cm} / \mathrm{yr}$ over the last 2,000 yr., spanning 14 seismic cycles. The time scale over which this variation is observed is essentially equivalent to that averaged by the youngest dated feature on the Kunlun Fault. The similarity of the cosmogenicderived slip rate on the Kunlun Fault to that derived from the essentially instantaneous geodetic results suggest that secular variations in slip-rate do not persist over $\sim 2000$ years

\subsubsection{Haiyuan Fault}

Together with the Altyn Tagh and Kunlun faults, the Haiyuan fault is one of the main leftlateral strike-slip faults defining the northeastern edge of Tibet. This 1000-km-long fault accommodates the eastward component of movement of Tibet relative to the Gobi- Ala Shan platform to the north (Tapponnier and Molnar, 1977; Zhang et al., 1988). The large 1920 Haiyuan $(M=8.7)$ and 1927 Gulang $(M=8-8.3)$ earthquakes occurred on and near the Haiyuan fault (Figure 8), and attest to its capacity to produce large earthquakes (Deng, 1986; Gaudemer et al., 1995; Zhang et al., 1987). In this connection, a $220-\mathrm{km}$-long seismic gap of great potential hazard has been identified along the western stretch of the fault near Tianzhu, (Gaudemer et al., 1995). The strike of the Haiyuan Fault is roughly parallel to that of the Kunlun fault (Fig. 1), but unlike the Kunlun which is defined by a single strand at most latitudes, the main Leng Long Ling segment of the Haiyuan fault splays into the Gulang and Maomao Shan faults at $\sim 102.5^{\circ} \mathrm{E}$ (Fig. 8). The partitioning of slip along these splays in the millennial slip-rates established by dating geomorphic offsets on the Maomao (Lasserre et al., 1999) and Leng Long Ling (Lasserre et al., 2002) segments of the fault.

Meyer (1991) and Gaudemer et al. (1995) identified moraine and glacial valley edge offsets, on the order of 200 to $270 \mathrm{~m}$, at several sites in the Leng Long Ling using SPOT images. In the absence of absolute chronological data, they inferred the offsets to have accrued in the period since the LGM or the onset of the Holocene yielding rates between 10 and $26 \mathrm{~mm} / \mathrm{yr}$. More recently, Lasserre et al. (2002) mapped a $200 \pm 40 \mathrm{~m}$ offset of the Xiying He moraine on the 
Leng Long Ling section of the fault. In situ ${ }^{10} \mathrm{Be}$ and ${ }^{26} \mathrm{Al}$ ages of samples collected from the ridge of the moraines cluster around 10,300 \pm 339 years. This age is interpreted as the time of last reshaping of the moraine before the valley glacier withdrew south of the fault around the end of the Younger Dryas ( 11,000 years B.P.). Assuming that the $200 \pm 40 \mathrm{~m}$ moraine offset was recorded after glacial retreat across the fault constrains the late Pleistocene slip rate on the Leng Long Ling segment of the Haiyuan fault to be $19 \pm 5 \mathrm{~mm} / \mathrm{yr}$. The cosmic-ray exposure dating of the Xiying He moraine offset thus confirms and refines the earlierr estimates of Meyer (1991) and Gaudemer et al. (1995).

West of the junction between the Gulang and Maomao Shan segments of the Haiyuan fault, ${ }^{14} \mathrm{C}$ dating of fluvial terrace risers near Songshan, on the Maomao Shan segment (Fig. 8), yields a slip-rate of $12 \pm 4 \mathrm{~mm} / \mathrm{yr}$ averaged over about 14,000 years (Lasserre et al., 1999). The eastward decrease in rate reflects the partitioning of slip between the Gulang and Maomao Shan splays of the fault. In this connection, the slip contribution of the Gulang fault was previously estimated to be $4.3 \pm 2.1 \mathrm{~mm} / \mathrm{yr}$ (Gaudemer et al., 1995), and is in agreement with the velocity decrease on the main southern segments of the Haiyuan, east of where the Gulang and Maomao Shan splays merge. A long-term sinistral slip-component as high as $\sim 2 \mathrm{~cm} / \mathrm{yr}$ between NE Tibet and the Gobi-Ala Shan platform east of $100^{\circ} \mathrm{E}$ has important implications for our understanding of the deformation of central Asia (Peltzer and Saucier, 1996). The geodetic rate of $8 \pm 2 \mathrm{~mm} / \mathrm{yr}$ inferred from regional GPS campaigns, which does not resolve the rates on the individual segments (Chen et al., 2000), is in agreement with the geomorphic rate from the Maomao segment, but somewhat lower than the geomorphic rate obtained from the Leng Long Ling segment. This may reflect either the still small number of measurement epochs and stations used in such studies, the large error on the geomorphic determination, or more fundamental differences in short and long-term crustal fault mechanics.

\subsubsection{The Altyn Tagh Fault}

The $2500 \mathrm{~km}$-long, left-lateral Altyn Tagh fault system defines the northern edge of the Tibetan plateau from Muztagh Ata Tagh, near $75^{\circ} \mathrm{E}$, to Yabraishan, east of $102^{\circ} \mathrm{E}$ (Figure 1), and has been interpreted as the main continental plate boundary guiding the northeastward extrusion of Tibet relative to the Tarim basin (Peltzer and Tapponnier, 1988; Tapponnier and Molnar, 1977). Seismic tomography suggests that a deep shear zone extend beneath the fault to the base of the lithosphere (Wittlinger et al., 1998, 2004), but the magnitude of the millennial and Cenozoic slip-rates and total offsets along the fault remain controversial with estimates of the sinistral slip-rate ranging from $2 \mathrm{~mm} / \mathrm{yr}$ to $40 \mathrm{~mm} / \mathrm{yr}$ (Bendick et al., 2000; Ge et al., 1992; Mériaux et al., 2004; Peltzer et al., 2000; Shen et al., 2001b; Wang et al., 2001; Washburn et al., 2001, 2004; Zhang et al., 2004). 
A number of total offset markers along the ATF have now been defined and the long-term Cenozoic, geologic slip-rates inferred. The majority of the pre-Tertiary piercing points are found along the central and eastern portions of the fault and yield offsets ranging from $260-500 \mathrm{~km}$ (Gehrels et al., 2003; Ritts and Biffi, 2000; Sobel et al., 2001; Yang et al., 2001; Yin et al., 2002; Yue et al., 2001). Near the western termination of the fault, Peltzer and Tapponnier (1988) noted that Paleozoic plutons in the western Kunlun have been offset by $>500 \mathrm{~km}$ across the ATF. A more recent reevaluation of this offset using additional age constraints yields a similar estimate of the total offset, $475 \pm 75 \mathrm{~km}$ (Cowgill et al., 2003). Based upon the history of sedimentation for the southwestern Tarim Basin, Qaidam Basin and Hexi corridor, Yin et al. (2002) infer that thrusting in the western Kunlun and along the Qiman Tagh and Northern Qaidam thrust systems began prior to $46 \mathrm{Ma}$ and $\sim 49 \mathrm{Ma}$, respectively. Interpreting these thrust systems as termination or branching faults of the ATF, they conclude that the ATF must have been active since $\sim 49 \mathrm{Ma}$, and that, combined with the $475 \pm 75 \mathrm{~km}$ offset of Paleozoic plutons in the western Kunlun, the long-term slip rate is $\sim 9 \mathrm{~mm} / \mathrm{yr}$. However, the temporal constraints must be viewed as somewhat controversial as the proposed initiation of slip on the ATF would predate that initiation of slip on the Red River Shear Zone, 36 Ma (Gilley et al., 2003), and slip on the Gangdese Thrust system, 27 Ma (Yin et al., 1994). Both features lie significantly closer to the Indo-Asian boundary and the proposed chronology would imply an "out-of-sequence" onset of continental deformation. In this connection others, e.g., Yue et al. (2001), have proposed an Oligo-Miocene initiation of slip on the ATF. As such, the $9 \mathrm{~mm} / \mathrm{yr}$ slip rate is best considered as a lower bound on the integrated Cenozoic slip-rate. Similarly, Yue et al. (2001) have reconstructed the offsets for the Xorkol basin $\left(91^{\circ}-92^{\circ} \mathrm{E}\right)$, north of the ATF and its inferred Oligocene, and post-Early Miocene source regions to the south, obtaining offsets of $\sim 380 \mathrm{~km}$ and $300 \mathrm{~km}$, respectively, yielding a long-term slip rate of 12-16 mm/yr. The Qilian Shan lies at the eastern termination of the ATF, a region of active shortening. Any post-Miocene shortening would result in an underestimate of the observed offset, and this observation may also constitute a lower bound.

Mériaux et al. (2004) have determined the ages of fluvial and glacial geomorphic markers left-laterally displaced along the central segment of the Altyn Tagh fault using radiocarbon and ${ }^{10} \mathrm{Be}-{ }^{26} \mathrm{Al}$ cosmic-ray exposure dating (Fig. 1). Two sites near Tura $\left(\sim 37.6^{\circ} \mathrm{N}, 86.6^{\circ} \mathrm{E}\right)$ were investigated: Cherchen He and Sulamu Tagh. Here, the ATF is characterized by a single strand, and geomorphic slip-rate determinations, therefore, capture the full rate on the fault. The sites are geomorphologically distinct with Cherchen He dominated by fluvial processes recording offsets between 166 - $420 \mathrm{~m}$, and the Sulamu Tagh by glacial action with offsets between $470-3660 \mathrm{~m}$. Nine offsets with ages between 6 and 113 ka yield a constant average slip rate of $26.9 \pm 6.9$ $\mathrm{mm} / \mathrm{yr}$ (Fig. 9), well in excess of the Cenozoic and geodetic slip-rate estimates (Bendick et al., 
2000; Wallace et al., 2004). The lack of secular variation of the rate is consistent with and extends the results obtained on the Kunlun Fault (Van der Woerd et al., 2000; Van der Woerd et al., 2002b; Van der Woerd et al., 1998).

With respect to the use and consistency of cosmogenic dating as applied to active tectonics, the Cherchen He site is of particular interest. At the Cherchen River site west of Tura, the ATF cuts fluvial terraces, offsetting their risers (T2/T1) and an abandoned channel ("PC"), (Fig. 10). The timing of terrace abandonment was determined by ${ }^{10} \mathrm{Be}$ and ${ }^{26} \mathrm{Al}$ cosmic-ray surface exposure dating of quartz cobbles from the surfaces of $\mathrm{T} 1$ and $\mathrm{T} 2$ and subsurface samples from $\mathrm{T} 1$. The average ages from cosmogenic dating of surfaces samples are 14.2 $\pm 1.3 \mathrm{ka}$ for T2 and $6.5 \pm 0.7$ ka for T1 (Fig. 11). The youngest depth-corrected ages for subsurface samples in the T1 depth profile yield a maximum age for the $\mathrm{T} 1$ surface ( $<6 \mathrm{ka} \mathrm{BP}$ ), in good agreement with the youngest surface ages. Three charcoal ages found in $\mathrm{T} 1$ on the east side of the site corroborate that this terrace was abandoned after $6.4 \pm 0.1 \mathrm{ka} \mathrm{BP}$. The agreement between the youngest ${ }^{10} \mathrm{Be}$ surface and subsurface cosmogenic ages and the radiocarbon data confirms that the older cosmogenic ages are "outliers" in the surface population likely due to pre-depositional exposure. The $166 \pm 10$ and $180 \pm 10 \mathrm{~m}$ offsets of the T2/T1 risers postdate the abandonment of T1, an incisional strath terrace, at $\sim 6 \mathrm{ka}$, and the $418 \pm 10 \mathrm{~m}$ offset of the abandoned fluvial channel must postdate abandonment of the T2 surface it incises. The age-offset pairs yield compatible rates of $25.7 \pm 3.3$ $\mathrm{mm} / \mathrm{yr}, 28.1 \pm 3.2 \mathrm{~mm} / \mathrm{yr}$ and $29.5 \pm 2.9 \mathrm{~mm} / \mathrm{yr}$. The 100,000 rate derived from offset glacial features at Sulamu Tagh, $\sim 50 \mathrm{~km}$ to the east, is $31.0 \pm 1.3 \mathrm{~mm} / \mathrm{yr}$, in agreement at the 2-sigma level.

The concordance of age determinations based on surface and subsurface cosmogenic ages and those based on "stratigraphically-correct" radiocarbon dating preclude any discernible effects of erosion and/or inheritance on the $\sim 15,000$ year slip-rate at Cherchen He. That the 100,000 year rate at Sulamu Tagh is consistent with this the Cherchen He rate suggests that the longer term measurement is similarly unaffected by erosion and/or inheritance. This will issue be discussed further below.

The eastern stretch (from $90^{\circ} \mathrm{E}$ to $97^{\circ} \mathrm{E}$ ) of the Altyn Tagh Fault strikes N70 $\mathrm{E}$ overall, but has a complex geometry (Fig. 12) that has been described in detail (Mériaux et al., 2005). Between the western edge of the Qaidam basin and the Qilian range, the fault system comprises three principal parallel strands (Ge et al., 1992; Meyer et al., 1998; Peltzer et al., 1989; Van der Woerd et al., 2001). The southern strand or South Altyn Tagh Fault (SATF) follows the Qaidam side of the Altyn push-up, and then veers southeastwards into the Tanghenan Shan. The northern strand follows the edge of the Tarim block from the Altyn to the Qilian Shan thrust fronts. East of the Qilian Shan front, the northern strand (NATF) continues with a N96 ${ }^{\circ}$ strike north of the 
Hexi corridor. Finally, the central strand or Yema Fault jogs southwards from the NATF between Aksay and Subei and continues northeastwards to the Taxue Shan thrust front.

The multiple strands and spatially related thrust faults that characterize the eastern ATF provide mechanisms for transfer of slip from the main segment of ATF, and eastward-decreasing geomorphic slip-rates do appear to confirm this effect. Millennial slip rates have been determined for the Altyn Tagh Fault at 3 sites near Aksay $\left(\sim 94^{\circ} \mathrm{E}\right)$ along the piedmont of the Dangjin Shankou range in northeastern Tibet through a combination of offset measurements of fluvial channels and terrace risers coupled with radiocarbon and ${ }^{10} \mathrm{Be}$ and ${ }^{26} \mathrm{Al}$ surface exposure dating (Mériaux et al., 2005). Cumulative offsets range from $20 \mathrm{~m}$ to $260 \mathrm{~m}$ and fall in distinct groups, indicative of climatically modulated regional landscape formation, and at least nine different surfaces have been defined based upon morphology, elevation and dating. The abandonment ages of several of these surfaces are constrained by radiocarbon dating of subsurface charcoals. The majority of the samples are younger than $\sim 14 \mathrm{ka}$, postdating the LGM. The end of the Early Holocene Optimum marks the boundary between the ages of the two main terrace levels at 5-6 ka. The radiocarbon ages typically coincide with the youngest cosmogenic ages for a particular surface. Surface exposure ages older than the radiocarbon dates are taken to represent diachronous terrace emplacement with a finite time interval between the onset of emplacement and abandonment. Explicit in this assumption is the possibility that some fraction of the offset of a terrace riser could have accumulated prior to abandonment of the underlying terrace. Slip-rates are obtained by matching the riser offsets with both (1) the abandonment/emplacement ages of the terrace underlying the riser and (2) the abandonment ages of the terrace levels above (the strath abandonment and strath emplacement models described earlier), and provide bounding estimates on the slip-rate (Fig. 13). Rates derived from channel offsets are determined using the age of the surface incised by the channel. Overall, slip-rate estimates using the abandonment age of the overlying level for fill terraces or channels and the emplacement of the underlying level for strath terraces give consistent results with 32 determinations yielding an average Holocene rate of $17.8 \pm 3.6 \mathrm{~mm} / \mathrm{yr}$ (Fig. 13). As the ATF is divided into a northern and southern branch at this longitude, the rate of the northern ATF should thus be considered a minimum for the overall Altyn Tagh Fault system. The ATF slip-rate at Aksay is $9 \mathrm{~mm} / \mathrm{yr}$ less than the geomorphic rate obtained near Tura at $\sim 87^{\circ} \mathrm{E}(26.9 \pm 6.9 \mathrm{~mm} / \mathrm{yr})$, in keeping with the inference of an eastward decreasing rate on the ATF, due to increased thrusting to the south.

Regardless of any spatial variability in slip-rate along the ATF, the difference in millennial and geodetic slip-rates is difficult to reconcile. For instance, GPS surveys across the central portion of the fault $\left(\sim 90^{\circ} \mathrm{E}\right)$ conducted in 1994, 1998 and 2002 yield a rate of $9 \pm 4 \mathrm{~mm} / \mathrm{yr}$ (Bendick et al., 2000; Wallace et al., 2004). Similarly, InSAR observation of the western 
Karakax Valley segment of the fault $\left(82^{\circ} \mathrm{E}\right.$, Fig. 1) yields a slip-rate of $5 \pm 5 \mathrm{~mm} / \mathrm{yr}$ (Wright et al., 2004). Both geodetic rates are substantially smaller than the millennial estimates. Wallace et al. (2004) conclude that the disparity is due to "systematic error that biases" geologic slip velocities to higher values. Given the agreement between radiocarbon, surface and subsurface cosmogenic dating, it is not clear what these "inescapable" biases might be. Instead, we emphasize that the slip-rate on the San Andreas Fault at Wrightwood have varied by a factor of $~ 3.5$ within the last 2000 years (Weldon et al., 2004). Secular variations of this magnitude would reconcile millennial and geodetic rates on the ATF, but the true nature and existence of this disparity must be confirmed by further millennial and decadal rate determinations.

\subsubsection{Karakorum Fault}

The Karakorum fault is the main Quaternary right-lateral fault north of the Himalayas and trends roughly parallel to the western Himalayan range, extending from at least Kailas to the Pamirs, a length of $>1200 \mathrm{~km}$ (Fig. 1). As the ATF defines the northern edge of Tibetan plateau, the Karakorum Fault defines at least the western portion of its southern border, and its slip-rate has similar implications for the rheological character of the continental lithosphere and is a subject of active debate. Attempts to determine the rate over timescales ranging from the OligoMiocene to the Quaternary have produced disparate values ranging from 1 to $30 \mathrm{~mm} / \mathrm{yr}$ (Banerjee and Burgmann, 2002; Brown et al., 2002a; Chevalier et al., 2005a; Lacassin et al., 2004; Liu, 1993; Murphy et al., 2002; Phillips et al., 2004; Wang et al., 2001; Wright et al., 2004).

Unlike the ATF, the disparity in rate estimates on the Karakorum Fault is not strictly a function of observational technique, however, and helps to point out an important distinction between estimates derived from geodesy and morphochronology. The InSAR observations of Wright et al. (2004) provide the most recent geodetic slip-rate estimate for the Karakorum Fault. Using observations taken between 1992 and 1999 they obtain a rate of $1 \pm 3 \mathrm{~mm} / \mathrm{yr}$. Based on cosmogenic dating, the geomorphic rate determined on a single strand of the Karakorum Fault north of Bangong Lake is $4 \pm 1 \mathrm{~mm} / \mathrm{yr}$ (Brown et al., 2002a), in apparent agreement with the geodetic results. However, this geomorphic rate must be considered a minimum value as it only samples the northern of the two strands of the fault at this longitude (Fig. 1). While geodetic methods sample far-field deformation, capturing all of the motion distributed among the various strands of a fault system, the geomorphic rates are only representative of the motion on the strand on which the offset is observed. Motion accommodated on other strands within the system must be measured independently. A similar debate concerns the integrated Oligio-Miocene slip-rate on the Karakorum. Phillips et al. (2004) estimate a total offset of $40-150 \mathrm{~km}$ to have 
accumulated on the fault west of Mount Kailas during the last $\sim 15 \mathrm{Myr}$, yielding an integrated rate of 2-10 mm/yr. Lacassin et al (2004) estimate a larger cumulate offset ( $250 \mathrm{~km})$ and earlier initiation of motion on this section of the fault $(\sim 23 \mathrm{Ma})$, yielding a rate at the upper end of that proposed by Phillips et al. (2004). More importantly, Lacassin et al. (2004) propose that dextral slip along the Indus-Tsangpo suture east of Mount Kailas may have accommodated a similar cumulative offset, doubling the total offset and associated slip-rate. Hence, the existing investigations of both the geologic and active slip-rates on the Karakorum Fault highlight the need for regional mapping of both active and geologic faults prior to smaller scale analysis and sampling and, that other factors aside, the rates on a single strand of a complex fault system are necessarily minimum values.

Chevalier et al. (2005) determined a millennial slip-rate on one branch of the Karakorum fault at the Manikala glacial valley terminus, west of the Gar basin $\left(32^{\circ} 2.529^{\prime} \mathrm{N}, 80^{\circ} 1.212^{\prime} \mathrm{E}\right.$, Fig. 14) using ${ }^{10} \mathrm{Be}$ surface exposure dating of dextrally offset moraines. The Manikala moraine complex lies at the base of the faulted Ayilari range-front, that bounds the west side of the Gar valley, a large pull-apart basin floored by marshland that hides other strands of the Karakorum fault system (Armijo et al., 1989) (Fig. 1). The dated moraines lie southeast of the U-shaped Manikala Valley, a glacial trough deeply entrenched into the range's igneous basement (Fig. 14). Within the till complex, two main groups of moraines are recognized (Fig. 14). All were emplaced by the Manikala Daer glacier, whose terminus is today $\sim 7 \mathrm{~km}$ upstream from the active fault trace. The morphology of the moraines indicates that they were formed during major advances of the glacier, and later abandoned when the glacier retreated upstream.

The relative ages of the moraine groups can be qualitatively assessed from their surface characteristics (Fig. 15). The M1 surface is rough and composed of chaotically distributed, imbricate blocks (as large as 3 meters) surrounded by coarse debris. The smoother surface of M2 appears older with blocks (tens of centimeters to a meter) protruding above a mantle of smaller debris (Fig. 15). The morainic ridges thus appear to become younger from east to west, consistent with right-lateral motion on the fault.

The M2 moraine complex is divided into eastern and western sections (M2E and M2W, respectively) by a deep, beheaded, flat-floored, valley (labeled "PV" in Fig. 14) that is flanked by well-defined, lateral moraines. The crest of the lateral moraine east of PV is well preserved, and its eastern edge extends to the base of the faceted range-front. There is no catchment on the mountain slope facing this valley, indicating that PV must correspond to a former channel of the Manikala glacier (Fig. 14). The youngest moraine group (M1, Fig. 14) is the only one present on both sides of the Manikala outwash valley, displaying well-preserved terminal lobes and sharply defined ridge-crests. The lateral limits of glacial incision in the basement upstream from the fault 
reach the base of the triangular facets on either side of the Manikala valley. Once restored using satellite images, the M1 and M2E offsets are $220 \pm 10 \mathrm{~m}$ and $1520 \pm 50 \mathrm{~m}$, respectively.

The peaks in the overall M1-M2 age distribution correspond to the coldest periods as derived from proxy paleo-temperature records (e.g., SPECMAP $\partial^{18} \mathrm{O}$ curve (Imbrie et al., 1984), 19, 36, 151, $182 \mathrm{ka}$, Fig. 16), and hence, to maximal glacial advance. In particular, the younger M2 samples, $140 \pm 5.5 \mathrm{ka}$, corresponds roughly to the glacial maximum at the end of MIS 6 (150 $140 \mathrm{ka}$ ), the older M1 subgroup, $40 \pm 3 \mathrm{ka}$, to the cold period at the end of MIS 3 ( 40 ka), and the youngest M1 samples, $21 \pm 1.0 \mathrm{ka}$, to the $\mathrm{LGM}(19 \mathrm{ka})$. The oldest ${ }^{10} \mathrm{Be}$ ages on M2E suggest that it was emplaced during the major glacial advance at the beginning of MIS 6, while the youngest ages on M2E are consistent with abandonment at $\sim 140 \mathrm{ka}$ at the beginning of the Eemian interglacial (Fig. 16). The bulk of the ages on the younger moraine, M1, are consistent with emplacement at $\sim 40 \mathrm{ka}$. However, the younger ages on this surface suggest that it was not abandoned until the onset of post-LGM warming after $\sim 20 \mathrm{ka}$.

Matching the $1520 \pm 50 \mathrm{~m}$ offset of the M2E lateral moraine with the sample ages that approximate the end of the MIS 6 glacial maximum $(140 \pm 5.5 \mathrm{ka})$ yields an average slip-rate of $10.9 \pm 0.6 \mathrm{~mm} / \mathrm{yr}$ (Fig. 17). Likewise, matching the $220 \pm 10 \mathrm{~m}$ offset of M1 with the age of the M1 LGM samples $(21 \pm 1.0 \mathrm{ka})$ yields a rate of $10.5 \pm 0.5 \mathrm{~mm} / \mathrm{yr}$, corresponding to a constant right-lateral slip-rate of $10.7 \pm 0.7 \mathrm{~mm} / \mathrm{yr}$ on this segment of the Karakorum Fault for the last 140,000 years, a rate at least ten times greater than that obtained by InSAR (Wright et al., 2004). The total rate of displacement between SW Tibet and the western Himalayas is greater because the normal component of throw on the main fault must be taken into account, along with slip accommodated on other active fault strands within and on the opposite side of the Gar pull-apart basin. The disagreement between the various geomorphic and geodetic slip-rate observations on the Karakorum fault is a subject of continuing debate (cf., Brown et al., 2005; Chevalier et al., $2005 \mathrm{~b}$ ) and is unlikely to be resolved without continuing investigations in these remote areas.

\subsection{Geomorphic rates of thrusting and crustal shortening}

The region located northeast of the Qaidam basin, between the Altyn Tagh and Haiyuan faults (Figure 1), is characterized by several large NW-SE trending ranges (Tapponnier and Molnar, 1977) that have been interpreted to grow as ramp anticlines on active thrusts of crustal scale (Meyer et al., 1998; Tapponnier et al., 1990). The northeastward propagation of the leftlateral Altyn-Tagh Fault, and the regional northeastward elevation decrease ( $\sim 3000 \mathrm{~m}$ to $1200 \mathrm{~m}$ a.s.1.), suggest a close relationship between sinistral faulting and thrusting in which sinistral motion along the ATF is transferred to the active thrust faults (Métivier et al., 1998; Meyer et al., 1998; Peltzer et al., 1988). The rates of both sinistral slip on the ATF and shortening across the 
thrusts should decrease due to the eastward transformation of lateral slip to shortening. In this region Quaternary rates of uplift and crustal shortening have been quantitatively determined for the Tanghenan Shan thrust (Van der Woerd et al., 2001), the Yumen Shan thrust (Hetzel et al., 2002) and the Zhangye thrust (Hetzel et al., 2004). All use the general strategy outlined in Figure 3; elevation profiles across the scarps and terraces are performed to obtain vertical offsets, coupled with either radiocarbon dating (Van der Woerd et al., 2001), cosmogenic dating (Hetzel et al., 2002) and combination of cosmogenic and optically stimulated luminescence (OSL) dating (Hetzel et al., 2004).

The Tanghenan Shan, Yumen Shan and Zhangye Shan thrusts occupy very different positions with respect to the eastern terminus of the ATF and the growing thrust bounded mountain ranges of the northeastern corner of Tibet. These differences appear to be reflected in the rates of uplift and shortening (Fig. 18). The Tanghenan Shan is one of the highest ranges (5500 m a.s.1.) north of the Qaidam with a length of $300 \mathrm{~km}$, between the Altyn Tagh Fault to the west and Hala $\mathrm{Hu}$ Lake to the east. Its structure and morphology are similar to the other actively growing ranges of this region, such as the Taxueh and Qilian Shan. The Tanghenan Shan thrusts are northeastvergent, the predominant trend in northeastern Tibet, and instead of being cut and displaced by strike-slip movement on the fault, as inferred by Wang (1997), the Tanghenan Shan (Fig. 18) appears to be a consequence of such movement (Meyer et al., 1998). North of Subei, the principal, northern branch of the Altyn Tagh Fault keeps striking $\sim \mathrm{N} 70^{\circ} \mathrm{E}$ across the Subei Basin (Ge et al., 1992; Meyer et al., 1996; Tapponnier et al., 1990), while the main Tanghenan Shan frontal thrust splays from it towards the southeast (Fig. 12 and 18). The southern branch of the Altyn Tagh Fault, west and south of the Subei branch follows the curved axis of the Tanghenan range. Such relationships between the sinistral faults, the range, and the thrust indicate that a fraction of the strike-slip motion is locally transformed into thrusting, folding and mountain building. Southeast of Subei, the Tanghenan Shan frontal thrust trace is displaced about $25 \mathrm{~km}$ northeastwards by the sinistral Yema Fault. Thrusting continues at least $150 \mathrm{~km}$ farther southeastwards along the south side of the Yanchiwan Basin (Meyer et al., 1998) (Fig. 18). All along the northern piedmont of the range, Neogene red beds, as well as the recent Quaternary terraces that unconformably cap them are folded and uplifted by active north-vergent thrusts.

The rates of uplift in the Tanghenan Shan have been constrained by ${ }^{14} \mathrm{C}$ dating of organic remains collected on different strath terraces (Van der Woerd et al., 2001). Most of the fans and terraces in the southern part of the Subei basin were emplaced after the last glacial maximum, many of them during the early Holocene optimum (9-5 ka). At one site the minimum vertical throw of $34 \pm 2 \mathrm{~m}$ of a surface dated at $8411 \pm 530 \mathrm{yr}$ BP, provides a minimum vertical uplift rate of $4.1 \pm 0.5 \mathrm{~mm} / \mathrm{yr}$. The maximum plausible uplift, deduced from stream incision and fold 
geometry, of the oldest terrace surface $(115 \pm 15 \mathrm{~m})$, whose probable age is 15 to $18 \mathrm{ka}$, places an upper bound on the uplift rate of $7 \pm 2 \mathrm{~mm} / \mathrm{yr}$. The thrust geometry at depth, and the cumulative shortening (9 to $12 \mathrm{~km}$ ) across the imbricate thrust-wedge, were deduced from balancing two sections logged in the field, and are consistent with a shortening rate of about $5 \mathrm{~mm} / \mathrm{yr}$ and an onset of thrusting along the south side of the Subei basin at about $3 \pm 1 \mathrm{Ma}$.

While the junction between the ATF and the Tanghenan Shan thrust is $~ 300$ west of the eastern terminus of the ATF, the Yumen Shan thrust lies $\sim 10 \mathrm{~km}$ east of the Qilian Shan at roughly the same longitude as the eastern terminus of the ATF. Unlike the Tanghenan Shan, which bounds a major mountain range, the Yumen Shan thrust, with opposite vergence, does not dip under a high mountain range (Meyer et al., 1998). While the Yumen Shan thrust may not be directly connected to the ATF, it is arguably the easternmost thrust that is spatially associated with the ATF. Hetzel et al. (2002) dated 5 uplifted terraces (up to $\sim 60 \mathrm{~m}$ above the active river) using ${ }^{10} \mathrm{Be},{ }^{26} \mathrm{Al}$ and ${ }^{21} \mathrm{Ne}$ cosmogenic dating, and demonstrate that the terraces at Yumen Shan record a protracted history of deposition and uplift extending to MIS-6 with ages ranging from 40-170 ka. The uplift rate obtained is bounded between $0.3-0.4 \mathrm{~mm} / \mathrm{yr}$, and is consistent with constant uplift and shortening over the observation interval (Fig. 19).

Projected along the regional strike of the Qilian Shan, the Zhangye Thrust's position relative to the terminus of the ATF is roughly equivalent to that of the Yumen Shan thrust (Fig. 18). However, unlike the Yumen Shan, the Zhangye Thrust is north-vergent and lies $\sim 250 \mathrm{~km}$ southeast of the terminus of the ATF, roughly midway between the ATF and Haiyuan Faults (Fig. 18). Hetzel et al. (2004) used a combination of ${ }^{10} \mathrm{Be}$ surface exposure and OSL dating of alluvial gravels and overlying loess deposits, respectively, to constrain the ages of terraces uplifted by 55$60 \mathrm{~m}$ and $25-30 \mathrm{~m}$ in the hanging wall of the thrust. The highest terrace yielded an age of $90 \pm 11$ kyr and the lower terrace $31 \pm 5 \mathrm{kyr}$ constraining the long-term uplift rate to $0.6-0.9 \mathrm{~mm} / \mathrm{yr}$. Assuming a dip of $40-60^{\circ}$, they obtain a shortening rate of $\sim 1 \mathrm{~mm} / \mathrm{yr}$.

While there are numerous additional thrusts between the Qaidam Basin and the Gobi-Ala Shan platform that have not been quantitatively dated, the results from those described here are in reasonable agreement with existing GPS data for the region (Chen et al., 2004; Chen et al., 2000; Zhang et al., 2004). For instance, as observed by Hetzel et al. (2004), two GPS estimated of shortening between the Qaidam and Hexi Corridor yield shortening rates of $5.4 \pm 1.8 \mathrm{~mm} / \mathrm{yr}$ (Chen et al., 2004) and $8.1 \pm 2.9 \mathrm{~mm} / \mathrm{yr}$ (Chen et al., 2000), consistent with the combined rates from the Tanghenan, Zhangye and Yuman Shan (assuming at dip of $40-60^{\circ}$ for the Yuman Shan). However, the rates of shortening for the individual faults decreases to the east, as demonstrated by the rates for the north-vergent Tanghenan and Zhangye thrusts. Interestingly, Meyer et al. (1998) estimated a shortening rate of $2.1 \pm 0.6 \mathrm{~mm} / \mathrm{yr}$ for a thrust in the piedmont of 
the Taxueh Shan., Taken together with the shortening rates for the Tanghenan and Zhangye thrusts the Taxueh Shan rate, though not confirmed by quantitative dating, would yield an eastwardly decreasing shortening rate consistent with models for the propagation of the ATF and asymmetric growth of the plateau via associated thrusting (Métivier et al., 1998; Meyer et al., 1998).

\section{4. "Systematic" underestimation of slip-rates - effects of erosion}

Perhaps the most striking feature of the assembled slip-rate data for central Asia is the disparity between geomorphic and geodetic slip-rate estimates on the Altyn Tagh and Karakorum faults; geomorphic rates are at least a factor of three or more higher than geodetic measurements. "Systematic" over-estimation of the rate by geomorphic methods has been called upon to explain this disparity, but the underlying reasons for this overestimation remain unexplained (cf, Wallace et al., 2004). The effects most likely to skew cosmic-ray exposure ages of depositional surfaces are (1) pre-depositional exposure to cosmic-rays, (2) post-depositional contamination of surfaces by younger material, and (3) erosion.

If unaccounted for pre-depositional exposure ("inheritance") will result in an apparent surface exposure age that is older than the true age of abandonment. Inheritance can be constrained by subsurface sampling (cf, Anderson et al., 1996; Hancock et al., 1999; Mériaux et al., 2004; Perg et al., 2003; Repka et al., 1997), and the convergence of surface and subsurface cosmogenic ages and radiocarbon dates from young surfaces $(<15 \mathrm{ka})$ at Cherchen He indicates that this approach is valid for fluvial/alluvial surfaces in Tibet (Mériaux et al., 2004). Over-estimating the surface age would result in underestimates of the true slip-rate, and this is not what is observed in Asia.

Post-depositional contamination can produce ages that are younger than the true age of abandonment. The most likely mode of post-depositional surface contamination in the settings discussed above is re-occupation of an abandoned fluvial terrace due to flooding, which is most likely for young terraces that are not separated either vertically or laterally from the active stream. Such a example has been described along the Kunlun Fault by Van der Woerd et al. (1998). A distinct cluster of young ages ( $\sim 250$ years) was observed on a terrace where the majority of the samples had ages $\sim 1500$ years. The surface was only $1.5 \mathrm{~m}$ above that active river. As this surface ages, the relative difference between the abandonment and "flood" components will decrease, having a smaller overall effect on the average age of the surface. Also, as the terrace is further removed from the site of the active river by tectonic activity and incision, it is less likely to be contaminated. More generally, subsurface sampling eliminates this effect, and in most 
cases, the subsurface cosmogenic ages and radiocarbon data agree with the youngest surface ages (Mériaux et al., 2004; Mériaux et al., 2005).

Erosion does have the potential to decrease the apparent age of the surface, and the ages reported above are generally "model ages" that assume zero erosion rate. The effect of erosion on model ages becomes important when the amount of material removed approaches the e-folding depth for the nuclide production $(\sim 50 \mathrm{~cm})$. As a result, the effect of erosion on model ages is most pronounced for older surfaces $(\sim 100,000$ years old, Fig. 20$)$. For instance, an erosion rate of $8 \mathrm{~m} / \mathrm{My}$ would yield a zero erosion rate model age of $\sim 66 \mathrm{ka}$ for a sample with a true exposure age of $\sim 100 \mathrm{ka}$. Similarly, a rate of $6 \mathrm{~m} / \mathrm{My}$ would reduce the model age of a $\sim 250 \mathrm{ka}$ sample to $\sim 110 \mathrm{ka}$. These erosion rates are similar to the maximum mean, alpine bedrock summit erosion rate, $7.6 \pm 3.9 \mathrm{~m} / \mathrm{Myr}$, determined for four ranges in the western United States (Small et al., 1997). Model ages for younger samples are less perturbed simply because they haven't existed long enough to remove the requisite amount of material under reasonable conditions of erosion. Nevertheless, factor of two variations in age can be produced if the effect of erosion is ignored for older samples.

In theory, the ${ }^{26} \mathrm{Al} /{ }^{10} \mathrm{Be}$ ratio can be used to constrain erosion rates. However, this is only the case for very old samples with negligible erosion rates (Bierman and Caffee, 2001; Nishiizumi et al., 1991). Erosion has an effect similar to increasing the decay constant and samples experiencing rapid erosion reach steady state before the ${ }^{26} \mathrm{Al} /{ }^{10} \mathrm{Be}$ ratio can deviate significantly from the production ratio. As a result, erosion rates are difficult to constrain using only ${ }^{10} \mathrm{Be}-{ }^{26} \mathrm{Al}$ systematics. In the absence of a direct method of assessing the effects of erosion on model ages, we appeal to other observations: (1) agreement with radiocarbon ages, (2) correlations between climate history and landscape formation, and (3) constancy of observed slip-rates with time.

The agreement between cosmogenic dates and radiocarbon data has been established in a number of investigations in central Asia. For instance, Van der Woerd et al. (2002b) have shown that the same slip-rate is obtained for the Kunlun fault using either ${ }^{14} \mathrm{C}$ or ${ }^{10} \mathrm{Be}^{26} \mathrm{Al}$ ages. At Cherchen He and Aksay, radiocarbon and ${ }^{10} \mathrm{Be}$ ages for the same surface are in good agreement (Mériaux et al., 2004; Mériaux et al., 2005). These surfaces are typically younger than $<15,000$ years old, and erosion is not expected to be a major contributor, controlling the cosmogenic nuclide concentration. The comparison is ultimately limited in applicability by the temporal range of the radiocarbon method.

It is generally appreciated that landscape evolution is modulated by climate change (e.g., (Bull, 1991), and that the ages of landscape features should be generally correlative with local and global climate history. The majority of terraces dated in central Asia postdate the Last Glacial 
Maximum (Mériaux et al., 2005). While fewer older surfaces have been dated, those that have appear to correlate with climate records. For instance, at Manikala valley on the Karakorum fault, the bulk of ages $>100$ ka correlate with the cool periods with MIS-6 and MIS-5e (Fig. 16), and has been interpreted to indicate the onset of moraine emplacement during MIS-6 and retreat at the end of MIS-5e. Similarly, the major glacial features at the Sulamu Tagh site on the central ATF also appear to have been abandoned during glacial retreat at the end of MIS-5e (Mériaux et al., 2004). Fluvial terrace emplacement and abandonment at Yumen Shan may also correlate with climate, with the two oldest terraces yielding model ages that are arguably consistent with warming trends during MIS-6 ( 170 ka) and the strong warming trend at the end of MIS-5e $(\sim 120 \mathrm{ka})$. The presence of MIS-5e and MIS-6 landscape formation events suggests synchronous landscape evolution spanning the plateau from the northern boundary of the Himalayas to the Qilian Shan. If these model ages were reduced by erosion and the true age of these samples was significantly older, representing older glacial cycles, then we would have to explain the apparent, continent-wide absence of MIS-5e and MIS-6 landscape features. Hence, the correlation suggests that the ages of the landscape features used to constrain geomorphic slip-rates have not been significantly affected by erosion.

The linearity of the offset $v s$. model age data for both strike-slip and thrust faults. (Fig. 8, 9, 13,17 , and 19) in itself constitutes a strong argument in favor of low erosion rates with negligible effect on the model ages. Over timescales of $10^{5}$ years, it is expected that, in general, large active strike-slip faults should slip at a constant rate. For instance, the slip rate on the Kunlun Fault has been shown to remain constant over the last 40,000 years (Van der Woerd et al., 2000; Van der Woerd et al., 2002b). Importantly, the slip rate obtained from the largest offset on the Kunlun Fault $(\sim 400 \mathrm{~m})$ was constrained by radiocarbon dating and, hence, not influenced by erosion. If erosion had played a significant role, the offset $v s$. model age trends at high erosion rates should depart from linearity (Fig. 21). Rates obtained from larger, older offsets would be higher than the true value as the effect of erosion on model ages is greatest for older samples (Fig. 20); the magnitude of the departure would decrease with offset. Attempts to apply linear fits to offset $v s$. "erosion influenced" model age data will result in higher slip rates and decreasing "goodness of fit" (as evidenced by increasing $M S W D=$ mean squared weighted deviation) as the erosion rate increases. For instance, assuming a set of offset and age uncertainties similar those on the central ATF (Mériaux et al., 2004), a constant slip rate of $30 \mathrm{~mm} / \mathrm{yr}$ yields a $M S W D \sim 0$. Erosion rates of $10 \mathrm{~m} / \mathrm{Myr}$ and $20 \mathrm{~m} / \mathrm{Myr}$ yield offset $v s$. model age fits with $M S W D$ equal to 1.58 and 4.4, respectively, and linear fits yield non-zero intercepts (Figure 21). Linear regression of the 6 offset-model age pairs from the Sulamu Tagh yields a slip rate of $32.6 \pm 2.8 \mathrm{~mm} / \mathrm{yr}$ with $M S W D=$ 0.04 (Mériaux et al., 2004). Regression of the combined Sulamu Tagh and Cherchen He offset 
vs. model age data (9 pairs) yields a slip rate of $31.7 \pm 1.9 \mathrm{~mm} / \mathrm{yr}$ with $M S W D=0.14$ (Mériaux et $a l ., 2004)$. The clear linearity of these trends is strong argument against significant erosional effects on the model ages and supports these model age-derived slip-rate estimates.

Based on the analysis above, we contend that the $\sim 0-250 \mathrm{ka}$ ages of depositional features used in constraining geomorphic slip-rate determinations in central Asia have not been significantly effected by erosion. This is somewhat surprising. Had these samples experienced high alpine bedrock erosion rates (Small et al., 1997), a model age-true age disparity should have been observed. The obvious conclusion is that these samples simply have not experienced such high rates, and/or do not erode like bedrock surfaces. In support of the former, the sites studied are clearly sites of deposition, not degradation, so the expectation is that erosion is not important. To the extent that it does occur, the processes of surface degradation for alluvium may be different from those that control bedrock erosion over the relevant timescale. Two surface degradation processes that clearly do occur are (1) the spallation of the surface pebbles, cobbles and boulders that form fresh the alluvial surfaces, and (2) headward stream erosion. For instance, at Cherchen $\mathrm{He}$, a section through the $\sim 6,000$ year old terrace show that they are composed of pebbles with diameters of $\sim 50 \mathrm{~cm}$, while the surface is composed of shattered pebbles, sand and minor loess (Figure 22). Pebbles with sizes similar to those observed in the subsurface are scarce. As radiocarbon ages and cosmogenic ages agree, this process of initial degradation does not seem to have affected the surface chronology within current resolution. As this process happens in less that 6,000 years, it would be even more difficult to resolve for older samples, and perhaps represents the effective starting surface morphology for cosmic-ray exposure. The other process that does occur is headward erosion of ephemeral streams and rills. This process can be seen along the edges of the Manikala moraines (Fig. 14). If samples are taken on portions of the surface that are not currently experiencing this process, then it should have no effect on the ages obtained. Neither spallation of surface pebbles (at least after the initial period of surface smoothing) or headward stream erosion need produce the same effect as erosion, which is to take samples from depth, and bring them closer to the surface, thereby underestimating the timeintegrated nuclide production rate.

\section{Conclusions}

The high elevation of the Tibetan plateau along with its generally arid environment results in high cosmogenic nuclide production rates and preservation of millennial offsets. The close association of high topography and tectonic activity has also resulted in climatically generated landscape features along active faults providing a variety of offset markers. Together these features make Central Asia an ideal place for the application of tectonic morphochronology using 
cosmic-ray exposure dating. Slip-rates on both strike-slip and thrust faults have been quantified in the time interval 2-250,000 years, realizing the extended temporal range of this technique in extending the observation interval relative to radiocarbon dating. Where data permit comparison of radiocarbon and cosmogenic dating generally agree and support the assertion that erosion, inheritance and post-depositional contamination have only negligible effects on the surface age determination. Subsurface dating, and multiple age determinations on surface samples are required to support this contention.

A striking feature of the relation between offset and age is its linearity, an observation that supports constant slip-rates over the observed interval. Equally striking are the relatively low geodetic rates relative to the geomorphic slip-rate determinations for the Altyn Tagh and Karakorum faults. Data from other sources suggest that faults may exhibit temporal variations in slip velocity at timescales shorter than sampled by geomorphic measurements (cf, Ambraseys, 1973; Bennett et al., 2004; Peltzer et al., 2000; Weldon et al., 2004). Like the North and East Anatolian Faults, the ATF and KKF represent a conjugate fault pair on a continental scale. If the disparate geodetic and geomorphic rates were the result of transient strain accumulation, as has been suggested for the conjugate Garlock and Blackwater Faults in southern CA (Peltzer et al., 2000), then one fault should have a geodetic rate greater than the millennial rate. Secular variations in slip-rate produced by such a mechanism are not consistent with the present data (both the KKF and ATF geomorphic rates are higher than geodetic), arguing against this mechanism as the source of this disagreement. The geodetic and geomorphic rates for the Kunlun fault are in reasonable agreement, however, suggesting that there is no fundamental reason for disagreement between these methods in spite of very different observation intervals. Similarly, the shortening rates obtained by geodetic and geomorphic measurements across the Qilian Shan are also in good agreement. Where large disparities exist, there appears to be no easy path to reconciliation other than continuing investigations, including the analysis of additional geomorphic sites along these faults, better control of tropospheric effects on InSAR and GPS derived rates and deployment of permanent GPS stations sufficiently far from the faults to eliminate contamination due to interseismic strain.

The disparity between geodetic and geomorphic rates notwithstanding, the geomorphic rates in northern Tibet support kinematic models that invoke block rheology and strain localization within the continental lithosphere (Peltzer and Tapponnier, 1988) coupled with intra-continental subduction and asymmetric growth of the northeastern edge of the plateau (Meyer et al., 1998; Tapponnier, 2002). For instance, the $\sim 25 \mathrm{~mm} / \mathrm{yr}$ rate on the central ATF (Mériaux et al., 2004) is consistent with that required by block kinematic models (Avouac and Tapponnier, 1993). The eastward decrease in the ATF slip-rate between Tura (Mériaux et al., 2004) and Aksay (Mériaux 
et al., 2005) along with the eastwardly decreasing rates of shortening on thrust faults near the terminus of the ATF (Hetzel et al., 2002; Hetzel et al., 2004; Van der Woerd et al., 2001) is consistent with the eastward propagation of the ATF and the partitioning of slip onto geneticallyrelated thrust faults (Meyer et al., 1998; Tapponnier, 2002).

In spite of recent efforts (Brown et al., 2002b; Chevalier et al., 2005a), the southern boundary of Tibet remains largely unexplored with respect to geomorphic rate determinations, and assessment of these data in the context of the various kinematic models of Asian deformation is premature. For instance, the geomorphic rate of $10 \mathrm{~mm} / \mathrm{yr}$ at Manikala (Chevalier et al., 2005a) is still lower than the $\sim 30 \mathrm{~mm} / \mathrm{yr}$ required by block kinematic models (Avouac and Tapponnier, 1993; Peltzer and Saucier, 1996). Whether this is the result of slip on other, as-yet uninvestigated, strands of the fault remains to be established, as are potential along-strike variations in velocity. In a similar connection the rate of motion along the Karakorum-Jiali Fracture Zone has not been quantitatively constrained by cosmogenic dating. The role of the KJFZ in transferring slip from the Karakorum fault to strike-slip faults in eastern Asia, e.g., the Jiali fault, is a critical element of rigid block models of Asian deformation. Given the distributed nature of these features and the more subdued topography, acquistion of these data presents a formidable challenge.

Acknowledgements. This work was performed under the auspices of the U.S. Department of Energy by University of California Lawrence Livermore National Laboratory under contract No. W-7405-Eng-48 under the sponsorship of the LDRD program and from the Institut National des Sciences de l'Univers, Centre National de la Recherche Scientifique (Paris, France) through programs IDYL and IT, and from the China seismological Bureau and the Ministry of Lands and Resources (Beijing, China).

\section{References}

Ambraseys, N. N., 1973, Value of historical record of earthquakes: Nature, v. 232, p. 375-379.

Anderson, R. S., Repka, J. L., and Dick, G. S., 1996, Explicit treatment of inheritance in dating depositional surfaces using in situ ${ }^{10} \mathrm{Be}$ and ${ }^{26} \mathrm{Al}$ : Geology, v. 24, no. 1, p. 47-51.

Armijo, R., Tapponnier, P., and Tonglin, H., 1989, Late Cenozoic right-lateral strike-slip faulting in Southern Tibet: Journal of Geophysical Research-Solid Earth and Planets, v. 94, no. B3, p. 2787-2838.

Avouac, J. P., and Peltzer, G., 1993, Active tectonics in Southern-Xinjiang, China - Analysis of terrace riser and normal-fault scarp degradation along the Hotan-Qira Fault System: Journal of Geophysical Research-Solid Earth, v. 98, no. B12, p. 21773-21807.

Avouac, J. P., and Tapponnier, P., 1992, Kinematic model of active deformation in Central-Asia: Comptes Rendus De L Academie Des Sciences Serie Ii, v. 315, no. 13, p. 1791-1798. 
-, 1993, Kinematic Model of Active Deformation in Central-Asia: Geophysical Research Letters, v. 20 , no. 10 , p. $895-898$.

Banerjee, P., and Burgmann, R., 2002, Convergence across the northwest Himalaya from GPS measurements: Geophysical Research Letters, v. 29, no. 13, p. Art. No. 1652.

Bendick, R., Bilham, R., Freymueller, J., Larson, K., and Yin, G. H., 2000, Geodetic evidence for a low slip rate in the Altyn Tagh fault system: Nature, v. 404, no. 6773, p. 69-72.

Bennett, R. A., Friedrich, A. M., and Furlong, K. P., 2004, Codependent histories of the San Andreas and San Jacinto fault zones from inversion of fault displacement rates: Geology, v. 32, p. 961-964.

Bierman, P. R., and Caffee, M. W., 2001, Slow rates of rock surface erosion and sediment production across the Namib Desert and escarpment, Southern Africa: American Journal of Science, v. 301, p. 326-358.

Bilham, R., Larson, K., Freymueller, J., Jouanne, F., LeFort, P., Leturmy, P., Mugnier, J. L., Gamond, J. F., Glot, J. P., Martinod, J., Chaudury, N. L., Chitrakar, G. R., Gautam, U. P., Koirala, B. P., Pandey, M. R., Ranabhat, R., Sapkota, S. N., Shrestha, P. L., Thakuri, M. C., Timilsina, U. R., Tiwari, D. R., Vidal, G., Vigny, C., Galy, A., and deVoogd, B., 1997, GPS measurements of present-day convergence across the Nepal Himalaya: Nature, v. 386, no. 6620, p. 61-64.

Brown, E. T., Bendick, R., Bourles, D., Gaur, V., Molnar, P., Raisbeck, G. M., and Yiou, F., 2002a, Slip rates of the Karakorum fault, Ladakh, India, determined using cosmic ray exposure dating of debris flows and moraines: Journal of Geophysical Research-Solid Earth, v. 107, p. Art. No. 2192.

Brown, E. T., Bendick, R., Bourles, D. L., Gaur, V., Molnar, P., Raisbeck, G. M., and Yiou, F., $2002 b$, Slip rates of the Karakorum fault, Ladakh, India, determined using cosmic ray exposure dating of debris flows and moraines: Journal of Geophysical Research-Solid Earth, v. 107 , no. B9.

Brown, E. T., Molnar, P., and Bourles, D. L., 2005, Comment on "Slip-rate measurements on the Karakorum Fault may imply secular variations in fault motion": Science, v. 309, no. 5739.

Bull, W. B., 1991, Geomorphic Responses to Climatic Change: New York, Oxford University Press, 326 p.

Burchfiel, B. C., King, R. W., Royden, L. H., E., W., Chen, Z., Zhang, X., and Zhao, J., 1998, GPS results from the entire eastern part of the Tibetan Plateau and its adjacent foreland and their tectonic interpretation,: Trans. Am. Geophys. Un., v. 79, p. 45.

Chen, Q. Z., Freymueller, J. T., Wang, Q., Yang, Z. Q., Xu, C. J., and Liu, J. N., 2004, A deforming block model for the present-day tectonics of Tibet: Journal of Geophysical Research-Solid Earth, v. 109, no. B1.

Chen, Z., Burchfiel, B. C., Liu, Y., King, R. W., Royden, L. H., Tang, W., Wang, E., Zhao, J., and Zhang, X., 2000, Global Positioning System measurements from eastern Tibet and their implications for India/Eurasia intercontinental deformation: Journal of Geophysical Research-Solid Earth, v. 105, no. B7, p. 16215-16227.

Chevalier, M.-L., Ryerson, F. J., Tapponnier, P., Finkel, R. C., Van der Woerd, J., Haibing, L., and Qing, L., 2005a, Slip-rates measurements on the Karakorum Fault may imply secular variations in fault motion: Science, v. 307, p. 411-414. 
Chevalier, M. L., Ryerson, F. J., Tapponnier, P., Finkel, R. C., Van Der Woerd, J., Li, H. B., and Liu, Q., 2005b, Response to comment on "Slip-rate measurements on the Karakorum Fault may imply secular variations in fault motion": Science, v. 309, no. 5739.

Cowgill, E., Yin, A., Harrison, T. M., and Wang, X. F., 2003, Reconstruction of the Altyn Tagh fault based on U-Pb geochronology: Role of back thrusts, mantle sutures, and heterogeneous crustal strength in forming the Tibetan Plateau: Journal of Geophysical Research-Solid Earth, v. 108 , no. B7.

Cui, Z., and Yang, B., 1979, On the Tuouohu-Maqu active fault zone: Northwest. Seism. J., v. 1, p. 57-61.

Deng, Q. D., 1986, Variations in the geometry and amount of slip on the Haiyuan (Nanxihaushan) fault zone, China, and the surface rupture of the 1920 Haiyuan earthquake, Earthquake source mechanics: Geophys. Monogr. Ser.: Washington, D.C., Am. Geophys. Un., p. 169-182.

England, P., and Houseman, G., 1986, Finite Strain calculations of continental deformation. 2. Comparison with the India-Asia Collision Zone: Journal of Geophysical Research-Solid Earth and Planets, v. 91, no. B3, p. 3664-3676.

England, P., and Molnar, P., 1997a, Active deformation of Asia: From kinematics to dynamics: Science, v. 278, no. 5338, p. 647-650.

-, 1997b, The field of crustal velocity in Asia calculated from Quaternary rates of slip on faults: Geophysical Journal International, v. 130, no. 3, p. 551-582.

Gaudemer, Y., Tapponnier, P., Meyer, B., Peltzer, G., Guo, S. M., Chen, Z. T., Dai, H. G., and Cifuentes, I., 1995, Partitioning of crustal slip between linked, active faults in the Eastern Qilian Shan, and evidence for a major seismic gap, the Tianzhu Gap, on the western Haiyuan Fault, Gansu (China): Geophysical Journal International, v. 120, no. 3, p. 599-645.

Ge, S., Shen, G., Wei, R., Ding, G., and Wang, Y., 1992, Active Altun Fault Zone Monograph: Beijing, China, State Seismological Bureau of China, 319 p.

Gehrels, G. E., Yin, A., and Wang, X. F., 2003, Detrital-zircon geochronology of the northeastern Tibetan plateau: Geological Society of America Bulletin, v. 115, no. 7, p. 881-896.

Gilley, L. D., Harrison, T. M., Leloup, P. H., Ryerson, F. J., Lovera, O. M., and Wang, J. H., 2003, Direct dating of left-lateral deformation along the Red River shear zone, China and Vietnam: Journal of Geophysical Research, v. 108, p. 2127.

Gu, G., Tinghaung, L., and Zheniliang, S., 1989, Catalogue of Chinese Earthquakes (1831 BC1969 AD): Beijing, China, Science Press.

Hancock, G. S., Anderson, R. S., Chadwick, O. A., and Finkel, R. C., 1999, Dating fluvial terraces with Be-10 and Al-26 profiles: application to the Wind River, Wyoming: Geomorphology, v. 27, no. 1-2, p. 41-60.

Herquel, G., Tapponnier, P., Wittlinger, G., Mei, J., and Danian, S., 1999, Teleseismic shear wave splitting and lithospheric beneath and across the Altyn Tagh fault: Geophysical Research Letters, v. 26, no. 21, p. 3225-3228.

Hetzel, R., Niedermann, S., Tao, M., Kubik, P. W., Ivy-Ochs, S., Gao, B., and Strecker, M. R., 2002, Low slip rates and long-term preservation of geomorphic features in Central Asia: Nature, v. 417, no. 6887, p. 428-432.

Hetzel, R., Tao, M. X., Stokes, S., Niedermann, S., Ivy-Ochs, S., Gao, B., Strecker, M. R., and Kubik, P. W., 2004, Late Pleistocene/Holocene slip rate of the Zhangye thrust (Qilian Shan, 
China) and implications for the active growth of the northeastern Tibetan Plateau: Tectonics, v. 23 , no. 6 .

Imbrie, J., Hays, J. D., Martinson, D. G., Mclntyre, A., Mix, A. C., Morley, J. J., Pisias, N. G., Prell, W. L., and Shackleton, N. J., 1984, The orbital theory of Pleistocene climate: Support from a revised chronology of the marine delta ${ }^{18} \mathrm{O}$ record, in Berger, A., Imbrie, J., Hays, J., Kukla, G., and Saltzman, B., eds., Milankovitch and Climate, Part I: Boston, Reidel, p. 269305.

Kidd, W. S. F., and Molnar, P., 1988, Quaternary and active faulting observed on the 1985 Academia- Sinica Royal-Society Geotraverse of Tibet: Philosophical Transactions of the Royal Society of London Series a-Mathematical Physical and Engineering Sciences, v. 327, no. 1594 , p. $337-\&$.

Lacassin, R., Valli, F., Arnaud, N., Leloup, P. H., Paquette, J. L., Haibing, L., Tapponnier, P., Chevalier, M. L., Guillot, S., Maheo, G., and Xu, Z. Q., 2004, Large-scale geometry, offset and kinematic evolution of the Karakorum fault, Tibet: Earth and Planetary Science Letters, v. 219, no. 3-4, p. 255-269.

Larson, K. M., Burgmann, R., Bilham, R., and Freymueller, J. T., 1999, Kinematics of the IndiaEurasia collision zone from GPS measurements: Journal of Geophysical Research-Solid Earth, v. 104, no. B1, p. 1077-1093.

Lasserre, C., Gaudemer, Y., Tapponnier, P., Meriaux, A. S., Van der Woerd, J., Yuan, D. Y., Ryerson, F. J., Finkel, R. C., and Caffee, M. W., 2002, Fast late Pleistocene slip rate on the Leng Long Ling segment of the Haiyuan fault, Qinghai, China: Journal of Geophysical Research-Solid Earth, v. 107, no. B11, p. art. no.-2276.

Lasserre, C., Morel, P. H., Gaudemer, Y., Tapponnier, P., Ryerson, F. J., King, G. C. P., Metivier, F., Kasser, M., Kashgarian, M., Baichi, L., Taiya, L., and Daoyang, Y., 1999, Postglacial left slip rate and past occurrence of $M>=8$ earthquakes on the western Haiyuan fault, Gansu, China: Journal of Geophysical Research-Solid Earth, v. 104, no. B8, p. 17633-17651.

Li, L., and Jia, Y., 1981, Characteristics of the deformation band of the 1937 Tuosuohu earthquake (M-7.5) in Qinhai: Northwest. Seism. J., v. 3, p. 61-65.

Liu, Q., 1993, Paléoclimat et Contraintes Chronologiques sur les Mouvemonts Récents dans l'Ouest du Tibet: Failles du Karakourm et de Longmu Co-Gozha Co, Lacs en Pull - Apart de Loungmu Co et de Sumxi Co [Ph.D. thesis]: L'Universite Paris VII, 360 p.

Massonnet, D., Rossi, M., Carmona, C., Adragna, F., Peltzer, G., Feigl, K., and Rabaute, T., 1993, The displacement field of the Landers earthquake mapped by radar interferometry: Nature, v. 364, no. 6433, p. 138-142.

Mériaux, A., Ryerson, F. J., Tapponnier, P., Van der Woerd, J., Finkel, R., Xu, X., Xu, Z., and Caffee, M. W., 2004, Rapid slip along the central Altyn Tagh Fault: Morphochronologic evidence from Cherchen He and Sulamu Tagh: Journal of Geophysical Research, v. 109, p. B06401.

Mériaux, A. S., Tapponnier, P., Ryerson, F. J., Xu, X. W., King, G., Van der Woerd, J., Finkel, R. C., Li, H. B., Caffee, M. W., Xu, Z. Q., and Chen, W. B., 2005, The Aksay segment of the northern Altyn Tagh fault: Tectonic geomorphology, landscape evolution, and Holocene slip rate: Journal of Geophysical Research-Solid Earth, v. 110, no. B4.

Métivier, F., Gaudemer, Y., Tapponnier, P., and Meyer, B., 1998, Northeastward growth of the Tibet plateau deduced from balanced reconstruction of two depositional areas: The Qaidam and Hexi Corridor basins, China: Tectonics, v. 17, no. 6, p. 823-842. 
Meyer, B., Tapponnier, P., Bourjot, L., Metivier, F., Gaudemer, Y., Peltzer, G., Shunmin, G., and Zhitai, C., 1998, Crustal thickening in Gansu-Qinghai, lithospheric mantle subduction, and oblique, strike-slip controlled growth of the Tibet plateau: Geophysical Journal International, v. 135 , no. 1, p. 1-47.

Meyer, B., Tapponnier, P., Gaudemer, Y., Peltzer, G., Guo, S. M., and Chen, Z. T., 1996, Rate of left-lateral movement along the easternmost segment of the Altyn Tagh fault, east of 96 degrees E (China): Geophysical Journal International, v. 124, no. 1, p. 29-44.

Molnar, P., and Lyon Caen, H., 1989, Fault plane solutions of earthquakes and active tectonics of the Tibetan Plateau and its margins: Geophysical Journal International, v. 99, no. 1, p. 123153.

Murphy, M. A., Yin, A., Kapp, P., Harrison, T. M., Manning, C. E., Ryerson, F. J., Ding, L., and Guo, J. H., 2002, Structural evolution of the Gurla Mandhata detachment system, southwest Tibet: Implications for the eastward extent of the Karakoram fault system: Geological Society of America Bulletin, v. 114, no. 4, p. 428-+.

Nishiizumi, K., Kohl, C. P., Arnold, J. R., Klein, J., Fink, D., and Middleton, R., 1991, Cosmic ray produced ${ }^{10} \mathrm{Be}$ and ${ }^{26} \mathrm{Al}$ in Antarctic rocks: exposure and erosion history: Earth and Planetary Science Letters, v. 104, p. 440-454.

Peltzer, G., Crampe, F., Hensley, S., and Rosen, P., 2001a, Transient strain accumulation and fault interaction in the Eastern California shear zone: Geology, v. 29, no. 11, p. 975-978.

Peltzer, G., Crampe, F., Hensley, S., and Rosen, P. A., 2000, Transient strain accumulation in the Eastern California Shear Zone: Transactions-American Geophysical Union, v. 81, p. F1244.

Peltzer, G., Crampe, F., and King, G., 1999, Evidence of nonlinear elasticity of the crust from the Mw 7.6 Manyi (Tibet) earthquake: Science, v. 286, no. 5438, p. 272-276.

Peltzer, G., Crampe, F., and Rosen, P., 2001b, The Mw 7.1, Hector Mine, California earthquake: surface rupture, surface displacement field, and fault slip solution from ERS SAR data: Comptes Rendus De L Academie Des Sciences Serie Ii Fascicule a-Sciences De La Terre Et Des Planetes, v. 333, no. 9, p. 545-555.

Peltzer, G., Hudnut, K. W., and Feigl, K. L., 1994, Analysis of coseismic surface displacement gradients using radar interferometry - New insights into the Landers Earthquake: Journal of Geophysical Research-Solid Earth, v. 99, no. B11, p. 21971-21981.

Peltzer, G., and Rosen, P., 1995, Surface Displacements of the 17 May 1993 Eureka Valley, California, Earthquake Observed By Sar Interferometry: Science, v. 268, no. 5215, p. 1333 1336.

Peltzer, G., and Saucier, F., 1996, Present-day kinematics of Asia derived from geologic fault rates: Journal of Geophysical Research-Solid Earth, v. 101, no. B12, p. 27943-27956.

Peltzer, G., and Tapponnier, P., 1988, Formation and evolution of strike-slip faults, rifts, and basins during the India-Asia Collision - an experimental approach: Journal of Geophysical Research-Solid Earth and Planets, v. 93, no. B12, p. 15085-15117.

Peltzer, G., Tapponnier, P., and Armijo, R., 1989, Magnitude of Late Quaternary left-lateral displacements along the north edge of Tibet: Science, v. 246, p. 1285-1289.

Peltzer, G., Tapponnier, P., Gaudemer, Y., Meyer, B., Guo, S. M., Yin, K. L., Chen, Z. T., and Dai, H. G., 1988, Offsets of Late Quaternary Morphology, Rate of Slip, and Recurrence of Large Earthquakes On the Chang Ma Fault (Gansu, China): Journal of Geophysical ResearchSolid Earth and Planets, v. 93, no. B7, p. 7793-7812. 
Perg, L. A., Anderson, R. S., and Finkel, R. C., 2002, Use of a new Be-10 and Al-26 inventory method to date marine terraces, Santa Cruz, California, USA: Reply: Geology, v. 30, no. 12, p. $1148-1148$.

-, 2003, Use of cosmogenic radionuclides as a sediment tracer in the Santa Cruz littoral cell, California, United States: Geology, v. 31, no. 4, p. 299-302.

Phillips, R. J., Parrish, R. R., and Searle, M. P., 2004, Age constraints on ductile deformation and long-term slip rates along the Karakoram fault zone, Ladakh: Earth and Planetary Science Letters, v. 226, no. 3-4, p. 305-319.

Repka, J. L., Anderson, R. S., and Finkel, R. C., 1997, Cosmogenic dating of fluvial terraces, Fremont River, Utah: Earth and Planetary Science Letters, v. 152, no. 1-4, p. 59-73.

Ritts, B. D., and Biffi, U., 2000, Magnitude of post-Middle Jurassic (Bajocian) displacement on the Altyn Tagh Fault, northwest China: Geological Society of America Bulletin, v. 112, p. 61-74.

Shen, F., Royden, L. H., and Burchfiel, B. C., 2001a, Large-scale crustal deformation of the Tibetan Plateau: Journal of Geophysical Research-Solid Earth, v. 106, no. B4, p. 6793-6816.

Shen, Z. K., Wang, M., Li, Y. X., Jackson, D. D., Yin, A., Dong, D. N., and Fang, P., 2001b, Crustal deformation along the Altyn Tagh fault system, western China, from GPS: Journal of Geophysical Research-Solid Earth, v. 106, no. B12, p. 30607-30621.

Sieh, K. E., and Jahns, R. H., 1984, Holocene activity of the San-Andreas Fault at Wallace-Creek, California: Geological Society of America Bulletin, v. 95, no. 8, p. 883-896.

Small, E. E., Anderson, R. S., Repka, J. L., and Finkel, R., 1997, Erosion rates of alpine bedrock summit surfaces deduced from in situ ${ }^{10} \mathrm{Be}$ and ${ }^{26} \mathrm{Al}$ : Earth and Planetary Science Letters, $\mathrm{p}$. submitted.

Sobel, E. R., Arnaud, N., Jolivet, M., Ritts, B. D., and Brunel, M., 2001, Jurassic to Cenozoic exhumation of the Altyn Tagh range, northwest China, constrained by ${ }^{40} \mathrm{Ar} /{ }^{39} \mathrm{Ar}$ and apatite fission track thermochronology, in Hendrix, M. S., and Davis, G. A., eds., Paleozoic and Mesozoic tectonic evolution fo central Asia: From continental assemblu to intracontinental deformation, Geological Society of America Memoir, p. 247-267.

Tapponnier, P., 2002, Oblique stepwise growth of the Tibet Plateau: Science, v. 295, no. 5553, p. 277-277.

Tapponnier, P., Meyer, B., Avouac, J. P., Peltzer, G., Gaudemer, Y., Guo, S. M., Xiang, H. F., Yin, K. L., Chen, Z. T., Cai, S. H., and Dai, H. G., 1990, Active thrusting and folding in the Qilian-Shan, and decoupling between upper crust and mantle in Northeastern Tibet: Earth and Planetary Science Letters, v. 97, no. 3-4, p. 382-403.

Tapponnier, P., and Molnar, P., 1977, Active faulting and tectonics in China: Journal of Geophysical Research, v. 82, no. 20, p. 2905-\&.

-, 1979, Active Faulting and Cenozoic Tectonics of the Tien Shan, Mongolia, and Baykal Regions: Journal of Geophysical Research, v. 84, no. B7, p. 3425-\&.

Tapponnier, P., Zhiqin, X., Meyer, B., Roger, F., Arnaud, N., Wittlinger, G., and Jingsui, Y., 2001, Asymmetric, stepwise rise and growth of the Tibet Plateau: Science, v. 294, p. 16711677. 
Van der Woerd, J., Meriaux, A.-S., Klinger, Y., Ryerson, F. J., Gaudemer, Y., and Tapponnier, P., 2002a, The November 14th, $2001 \mathrm{Mw}=7.8$ Kokoshili earthquake in Northern Tibet (Qinghai Province, China): Seismological Research Letters, v. 73, p. 125-135.

Van der Woerd, J., Ryerson, F. J., Tapponnier, P., Meriaux, A. S., Gaudemer, Y., Meyer, B., Finkel, R. C., Caffee, M. W., Zhao, G. G., and Xu, Z. Q., 2000, Uniform slip-rate along the Kunlun Fault: Implications for seismic behaviour and large-scale tectonics: Geophysical Research Letters, v. 27, no. 16, p. 2353-2356.

Van der Woerd, J., Tapponnier, P., Ryerson, F. J., Meriaux, A. S., Meyer, B., Gaudemer, Y., Finkel, R. C., Caffee, M. W., Zhao, G. G., and Xu, Z. Q., 2002b, Uniform postglacial sliprate along the central $600 \mathrm{~km}$ of the Kunlun Fault (Tibet), from Al-26, Be-10, and C-14 dating of riser offsets, and climatic origin of the regional morphology: Geophysical Journal International, v. 148, no. 3, p. 356-388.

Van der Woerd, J., Xu, X., Li, H. B., Tapponnier, P., Meyer, B., Ryerson, F. J., Meriaux, A. S., and $\mathrm{Xu}, \mathrm{Z}$. Q., 2001, Rapid active thrusting along the northwestern range front of the Tanghe Nan Shan (western Gansu, China): Journal of Geophysical Research-Solid Earth, v. 106, no. B12, p. 30475-30504.

Van der Woerd, J. W., Ryerson, F. J., Tapponnier, P., Gaudemer, Y., Finkel, R., Meriaux, A. S., Caffee, M., Zhao, G. G., and He, Q. L., 1998, Holocene left-slip rate determined by cosmogenic surface dating on the Xidatan segment of the Kunlun fault (Qinghai, China): Geology, v. 26, no. 8, p. 695-698.

Wallace, K., Yin, G. H., and Bilham, R., 2004, Inescapable slow slip on the Altyn Tagh fault: Geophysical Research Letters, v. 31, no. 9, p. - .

Wang, Q., Zhang, P. Z., Freymueller, J. T., Bilham, R., Larson, K. M., Lai, X., You, X. Z., Niu, Z. J., Wu, J. C., Li, Y. X., Liu, J. N., Yang, Z. Q., and Chen, Q. Z., 2001, Present-day crustal deformation in China constrained by global positioning system measurements: Science, v. 294 , no. 5542, p. 574-577.

Wang, Q., Zhang, P. Z., Niu, Z. J., Freymueller, J. T., Lai, X., Li, Y. X., Zhu, W. Y., Liu, J. N., Bilham, R., and Larson, K. M., 2002, Present-day crustal movement and tectonic deformation in China continent: Science in China Series D-Earth Sciences, v. 45, no. 10, p. 865-874.

Washburn, Z., Arrowsmith, J. R., Forman, S. L., Cowgill, E., Wang, X. F., Zhang, Y. Q., and Chen, Z. L., 2001, Late Holocene earthquake history of the central Altyn Tagh fault, China: Geology, v. 29, no. 11, p. 1051-1054.

Weldon, R., Scharer, K., Fumal, T., and Biasi, G., 2004, Wrightwood and the earthquake cycle: What a long recurrence record tells us about how faults work: GSA Today, v. 14, p. 4-10.

Weldon, R. J., and Sieh, K. E., 1985, Holocene rate of slip and tentative recurrence interval for large earthquakes on the San-Andreas Fault, Cajon-Pass, Southern-California: Geological Society of America Bulletin, v. 96, no. 6, p. 793-812.

Wittlinger, G., Tapponnier, P., Poupinet, G., Mei, J., Danian, S., Herquel, G., and Masson, F., 1998, Tomographic evidence for localized lithospheric shear along the Altyn Tagh fault: Science, v. 282, no. 5386, p. 74-76.

Wright, T. J., Parsons, B., England, P. C., and Fielding, E. J., 2004, InSAR observations of low slip rates on the major faults of western Tibet: Science, v. 305, no. 5681, p. 236-239.

Xu, X. W., Tapponnier, P., Van Der Woerd, J., Ryerson, F. J., Wang, F., Zheng, R. Z., Chen, W. B., Ma, W. T., Yu, G. H., Chen, G. H., and Meriaux, A. S., 2005, Late quaternary sinistral 
slip rate along the Altyn Tagh Fault and its structural transformation model: Science in China Series D-Earth Sciences, v. 48, no. 3, p. 384-397.

Yang, J., Xu, Z., Zhang, J., Chu, C.-Y., Zhang, R., and Liou, J. G., 2001, Tectonic significance of early Paleozoic high-pressure rock in the Altun-Qaidam-Qilian Mountains, northwest China, in Hendrix, M. S., and Davis, G. A., eds., Paleozoic and Mesozoic tectonic evolution of central Asia: From continental assembly to intracontinental deformation, Geological Society of America Memoir, p. 151-170.

Yin, A., Harrison, T. M., Ryerson, F. J., Chen, W. J., Kidd, W. S. F., and Copeland, P., 1994, Tertiary structural evolution of the Gangdese Thrust System, Southeastern Tibet: Journal of Geophysical Research-Solid Earth, v. 99, no. B9, p. 18175-18201.

Yin, A., Rumelhart, P. E., Butler, R., Cowgill, E., Harrison, T. M., Foster, D. A., Ingersoll, R. V., Zhang, Q., Zhou, X. Q., Wang, X. F., Hanson, A., and Raza, A., 2002, Tectonic history of the Altyn Tagh fault system in northern Tibet inferred from Cenozoic sedimentation: Geological Society of America Bulletin, v. 114, no. 10, p. 1257-1295.

Yue, Y. J., Ritts, B. D., and Graham, S. A., 2001, Initiation and long-term slip history of the Altyn Tagh fault: International Geology Review, v. 43, no. 12, p. 1087-1093.

Zhang, P., Molnar, P., Burchfiel, B. C., Royden, L., Wang, Y., Deng, Q., and Song, F., 1988, Bounds on the Holocene slip-rate on the Haiyuan Fault, north-central China: Quaternary Research, v. 30, p. 151-164.

Zhang, P., Z., S., M., W., W., G., Bürgmann, R., Molnar, P., Q., W., Z., N., J., S., J., W., H., S., and X., Y., 2004, Continuous deformation of the Tibetan Plateau from global positioning system data: Geology, v. 32, p. 809-812.

Zhang, W. Q., Jiao, D. C., Zhang, P. Z., Molnar, P., Burchfiel, B. C., Deng, Q. D., Wang, Y. P., and Song, F. M., 1987, Displacement along the Haiyuan Fault associated with the Great 1920 Haiyuan, China, Earthquake: Bulletin of the Seismological Society of America, v. 77, no. 1, p. $117-131$. 


\section{Figure Captions}

Figure 1. Kinematic map of active faults in Tibet displaying the geomorphic slip rate determinations constrained by cosmogenic, radiocarbon and OSL dating. Red boxes are location of slip rates determinations on strike-slip faults (M1: (Mériaux et al., 2004); M2: (Mériaux et al., 2005); V: (Van der Woerd et al., 2002b); L1: (Lasserre et al., 1999); L2: (Lasserre et al., 2002); C: (Chevalier et al., 2005a); B: (Brown et al., 2002a)). The green boxes are sites where shortening rates have been determined by dating uplifted terraces (V2: (Van der Woerd et al., 2001); H1: (Hetzel et al., 2002); H2: (Hetzel et al., 2004)).

Figure 2 Development of offset terraces associated with strike-slip movement along an active fault. Block diagrams showing plausible sequence of terrace emplacement and stream entrenchment disrupted by strike-slip faulting across bajada in rangefront piedmont basin. (1) emplacement of large fan T3 (fill) at time of large sedimentary discharge. Fault trace is buried. (2) after period of energetic discharge, stream incises channel T2. T3 surface is abandoned and begins to record faulting but the riser is constantly refreshed by lateral cutting. (3) during new episode of entrenchment, T2 (strath) is abandoned and riser T3/T2, now passive marker, begins to record lateral displacement. Age of T2 abandonment dates riser offset. (4) successive episodes of terrace beveling and entrenchment of stream due to climatic variation and stream profile evolution lead to formation of several terraces whose risers are offset differently. All episodes may not be recorded by all rivers and older terraces can be eroded by further incision (see right bank of stream, for example). (5) similar situation with small vertical slip component. Vertical offset accumulates when terrace is abandoned by stream. Hence vertical offset of T1 (or T2) is correlated to horizontal T2/T1 (or T3/T2) riser offset, and correlated offsets have ages of T1, or $\mathrm{T} 2$, respectively.

Figure 3 Sequential development of uplifted terraces associated with an active thrust fault. (A) Active stream with stable active terrace, T2. (B) Motion on fault cuts T2, and uplifts T2 terrace in hanging wall of the thrust. (C) Renewed incision causes abandonment of T2 and formation of younger $\mathrm{T} 1$ terrace. $(\mathrm{D}, \mathrm{E})$ Continued uplift and incision produces a series of perched terraces uplifted above the active river. Vertical offsets, ages and fault geometry can be used to determine rates of slip, uplift and shortening.

Figure 4. Uplifted fluvial terraces in the hanging wall of the Tanghenan Shan thrust near Yanchiwan $\left(\sim 96^{\circ} \mathrm{E}, 39^{\circ} \mathrm{N}\right)$. 
Figure 5. Relationship of surface and subsurface cosmogenic isotope compositions. (A) Surface age frequency distribution in which the "abandonment age" (dark gray) has been mixed with a younger population introduced by surface contamination, but contains no inherited component. Subsurface samples are free of surface contamination, and as there is no inheritance, follow an exponential decrease with depth, reaching zero concentration at the shielding depth. (B) Surface age frequency distribution in which the "abandonment age" (dark gray) has been mixed with a younger population introduced by surface contamination, and an older population associated with inheritance. Subsurface samples are surface contamination-free, but inherited component varies from sample to sample. Amalagmation of multiple samples allows the average inheritance, $\mathrm{I}_{0}$, and average exposure concentrations, $\mathrm{I}_{\exp }$ to be determined (Anderson et al., 1996; Hancock et al., 1999; Perg et al., 2002; Repka et al., 1997). (C) Similar to B, but with sampling of individual cobbles (filled symbols) instead of amalgamated samples. Since subsurface samples can only be perturbed by inheritance, a limiting isochron can be established providing a maximum age for the surface (Mériaux et al., 2004).

Figure 6. Large-scale segmentation of Kunlun Fault (after Van der Woerd et al., 2002b). From $91^{\circ} \mathrm{E}$ to $105^{\circ} \mathrm{E}$, six segments are identified. The Min Shan segment $\left(103^{\circ} \mathrm{E}\right.$ to $\left.105^{\circ} \mathrm{E}\right)$ steps about $50 \mathrm{~km}$ to the north. West of $91^{\circ} \mathrm{E}$, several segments, with strikes between N70 and N120, linked with normal faults form broad western horsetail termination. Instrumental (USGS 1977-1998) and historical (Gu et al., 1989) seismicity, filled and open circles, respectively, for magnitude Ms $>4$. Focal mechanisms from Molnar and Lyon-Caen (1989) and USGS.

Figure 7. Summary of Late Pleistocene-Holocene left-slip rates deduced from cosmogenic ${ }^{10} \mathrm{Be}-{ }^{26} \mathrm{Al}$ and ${ }^{14} \mathrm{C}$ dating of alluvial terraces at six sites along the Kunlun fault. Consistency between independent values obtained with different dating techniques implies uniform average slip-rate of $11.5 \pm 2 \mathrm{~mm} / \mathrm{yr}$ along $600 \mathrm{~km}$ of fault (Van der Woerd et al., 2000; Van der Woerd et al., 2002b; Van der Woerd et al., 1998).

Figure 8. (a) Tectonic map of India-Asia collision zone (after (Lasserre et al., 2002). Haiyuan fault is outlined in gray. Shaded region in inset shows location of SPOT mosaic. (b) Mosaic of SPOT images. Faults are from fieldwork and SPOT and Landsat images analysis. Tianzhu seismic gap (Gaudemer et al., 1995) is outlined in white. Locations of 1920 and 1927 (dark gray dots), M8 earthquakes are from (Gaudemer et al., 1995). Arrows point to study sites where Haiyuan fault slip rate was determined from measurements and dating of geomorphic features offset by the fault:, Maomao segment: $12 \pm 4$ ([L1]: Lasserre et al., 1999); Leng Long Ling segment: $19 \pm 5$ ([L2]: Lasserre et al., 2002). The rate on the Gulang fault [G1], $4.3 \pm 2.1 \mathrm{~mm} / \mathrm{yr}$, 
is an estimate from Gaudemer et al., (1995).

Figure 9. Slip-rate summary on the central Altyn Tagh fault during the last glacial cycle (Mériaux et al., 2004). Open symbols are the preferred slip-rate estimates yielding a bracket of 25-35 mm/yr; the lower bound is largely controlled by the Cherchen He data. The linear regression of the 9 data points that determine the upper slip rate estimates yields a rate of $31.3 \pm$ $1.0 \mathrm{~mm} / \mathrm{yr}$.

Figure 10. Offset terrace risers and channels of tributaries of Cherchen He west of Tura $\left(37.6^{\circ} \mathrm{N}\right.$, $86.4^{\circ} \mathrm{E}, \sim 3000 \mathrm{~m}$ a.s.1). a. Corona image (DS 1025-2118DA031) (Mériaux et al., 2004). b. Results of field mapping. Locations of surface samples are designated as $\diamond$, DP indicates the locations of subsurface sampling for cosmogenic dating. Terrace surfaces are numbered and shaded as a function of increasing age and elevation. WS is the western stream, ES the eastern stream and PC and RG are the paleochannel and regressive channel in incised T2 terrace, respectively. Measured riser and stream offsets, and average terrace ages are shown.

Figure 11. ${ }^{10} \mathrm{Be}$ exposure model age determinations at Cherchen He (Mériaux et al., 2004). The average values are a simple unweighted means with errors equal to one standard deviation for surface samples. The $1 \sigma$ brackets on the average ages are shown as the shaded regions on the figure. ${ }^{10} \mathrm{Be}$ ages of samples included in the average are shown as open symbols, solid symbols are for ages that were considered as outliers. Surface samples are shown as open and filled circles and depth-corrected ages of subsurface samples are shown as open and filled squares. Radiocarbon ages are shown as open triangles. Surface samples yield an average age of $7.3 \pm 2.2$ $\mathrm{ka}$ for $\mathrm{T} 1$ and an average of $16.6 \pm 3.9 \mathrm{ka}$ for T2. Sample TU3-71, $71.8 \pm 4.6 \mathrm{ka}$ has not been plotted in order to improve the resolution in the age range of interest.

Figure 12. Aksay segmentation map. Tectonic map of northern Tibet. a) Topography and active faulting along the eastern Altyn Tagh fault system (modified from (Meyer et al., 1998; Tapponnier et al., 1990; Van der Woerd et al., 2001)). b) Segmentation and main junctions of the ATF system from the Pingding Shan to the Qilian Shan (after(Mériaux et al., 2005).

Figure 13. Aksay offset vs age. Rates derived from the fill abandonment models and strath emplacement models yield an average Holocene rate of $18.0 \pm 3.6 \mathrm{~mm} / \mathrm{yr}$ (after (Mériaux et al., 2005).

Figure 14. (A) IKONOS satellite image of abandoned Manikala glacier moraines offset by Karakorum Fault. Present-day Manikala glacier outwash (lower right corner of image) is frozen (white). Note abandoned glacial channel (PV, paleovalley of Manikala glacier) east of the 
Manikala outwash. (B) Map of offset moraines (orange, M2, yellow, M1) and sample locations (circles with numbers). Thin lines outline main geomorphic features. Moraines M1 and M2E are offset $\sim 220$ and $1520 \mathrm{~m}$, respectively (see Fig. S3 and S4 for offset restorations) (from (Chevalier et al., 2005a).

Figure 15. Manikala surfaces IKONOS images of lateral moraine crests M1 (A) and M2 (B) showing different surface morphology correlated with different age. Large blocks (dark) are visible on both moraines. (C) Field photograph of the M1 surface. Large block in the center of the image is $\sim 2 \mathrm{~m}$ across. (D) Field photograph of the M2 surface (from (Chevalier et al., 2005a).

Figure 16. Manikala ages plus SPECMAP. (A) ${ }^{10} \mathrm{Be}$ exposure ages of blocks sampled along M1 and M2 moraine crests. (B) Comparison of age distribution (10 ka bins) with SPECMAP $\delta^{18} \mathrm{O}$ proxy climate curve, $\delta^{18} \mathrm{O}$ increases during glacial advances as ${ }^{16} \mathrm{O}$ is preferentially sequestered in the polar ice caps), shows a simple correlation of main moraine emplacement periods with coldest epochs of Marine Isotope Stage MIS-6 and MIS-3 and MIS-2 (LGM).

Figure 17. (A) Rates obtained from the offset age relationships for the Manikala moraine complex (Chevalier et al., 2005a). An average rate of $10.7 \pm 0.7 \mathrm{~mm} / \mathrm{yr}$ is obtained from linking the $1520 \pm 50 \mathrm{~m}$ and $220 \pm 10 \mathrm{~m}$ offsets with the end of MIS $6(\sim 140 \mathrm{ka})$ and MIS $2(\sim 20 \mathrm{ka})$, respectively. This association yields a constant slip-rate over the entire observation interval. A slip-rate of $5.5 \mathrm{~mm} / \mathrm{yr}$ is implied if the $220 \pm 10 \mathrm{~m}$ is linked with the $40 \pm 3 \mathrm{ka}$ age of the older subgroup on M1. This low slip-rate over the last $\sim 40 \mathrm{ka}$ requires a rate of $9.2 \mathrm{~mm} / \mathrm{yr}$ between $40 \mathrm{ka}$ and $\sim 180 \mathrm{ka}$ to reconcile the rate obtained if the $1520 \pm 50 \mathrm{~m}$ offset is linked with the 181 \pm 14 ka age cluster on M2E.

Figure 18. Seismotectonic map of northeast corner of Tibet (modified from (Tapponnier et al., 1990) and (Meyer et al., 1998). Note linear $\mathrm{N} 70^{\circ} \mathrm{E}$ striking left-lateral Altyn Tagh Fault at western terminations of Qilian, Daxue and Tanghe Nan Shan. N120 E striking Tanghe Nan Shan veers counter-clockwise to WSW before meeting with Altyn Tagh Fault west of Subei. About 5 earthquakes with magnitude between 5 and 6.1 occurred along Tanghe Nan Shan since 1960. Fault plane solution for one event is from (Molnar and Lyon Caen, 1989). The nodal planes strike parallel to the range, compatible with north vergent thrust. Inset is location of figure within Asia. The boxes show the study areas of Van der Woerd et al. (2001) [V2] and Hetzel et al. (2002) [H]. Figure 19. Plot of exposure ages versus heights of the different terraces. Error bars indicate $2 \sigma$ values (Hetzel et al., 2002). Three dashed lines indicate constant rates of river incision and tectonic uplift of $0.3,0.35$, and $0.4 \mathrm{~mm} / \mathrm{yr}$. 
Figure 20. Effects of erosion on model ages. The zero erosion rate model ages for samples with ${ }^{10} \mathrm{Be}$ concentrations similar to those from the Sulamu Tagh site along the central ATF (Mériaux et al., 2004) are shown along the abscissa. The curves indicate the true exposure age of a sample with these model ages for different erosion rates. Samples with model ages less than $\sim 60 \mathrm{ky}$, are not significantly affected by erosion, but model ages for older samples can be significantly perturbed.

Figure 21. Effects of erosion rate on the apparent slip rate for a fault with a constant slip rate over time. For a fixed set of offset measurements, we assume a slip rate of $30 \mathrm{~mm} / \mathrm{yr}$ with offsets, ages and errors similar to those observed at Sulamu Tagh (Mériaux et al., 2004). For the 10 and $20 \mathrm{~m} / \mathrm{Myr}$ erosion rate models we assume that the age is the same as in the zero erosion rate model, but recalculate the nuclide abundance for the different erosion rates. A "zero erosion rate model age" is then derived from these "erosionally decreased" nuclide concentrations. The zero erosion rate model ages generated for different erosion rates are then plotted against the observed offsets. The effect of erosion in decreasing the model ages is most apparent for the oldest samples, and as erosion rate increases, the slip rate plots depart from linearity and the apparent slip rate increases dramatically.

Figure 22. Surface and subsurface samples at Cherchen He on the Altyn Tagh fault near Tura. The exposed active terrace riser (A) shows that the subsurface is composed of pebbles on the order of $50 \mathrm{~cm}$ in diameter and below. The surface (B) is largely composed of shattered boulders, sand and minor loess. In spite of the surface processing, radiocarbon, depth-corrected subsurface and surface cosmogenic ages all agree. 


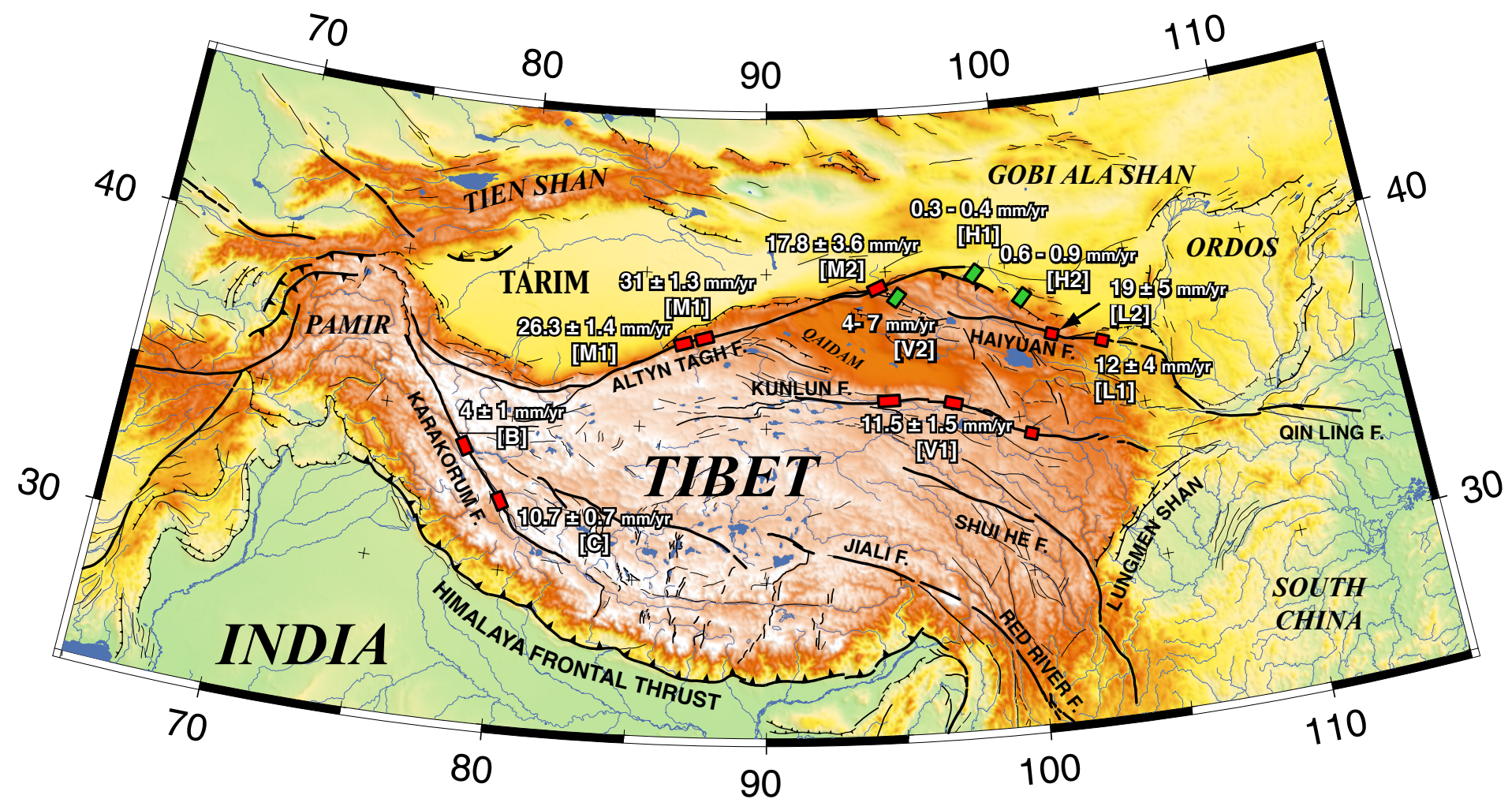

Figure 1. Ryerson et al 


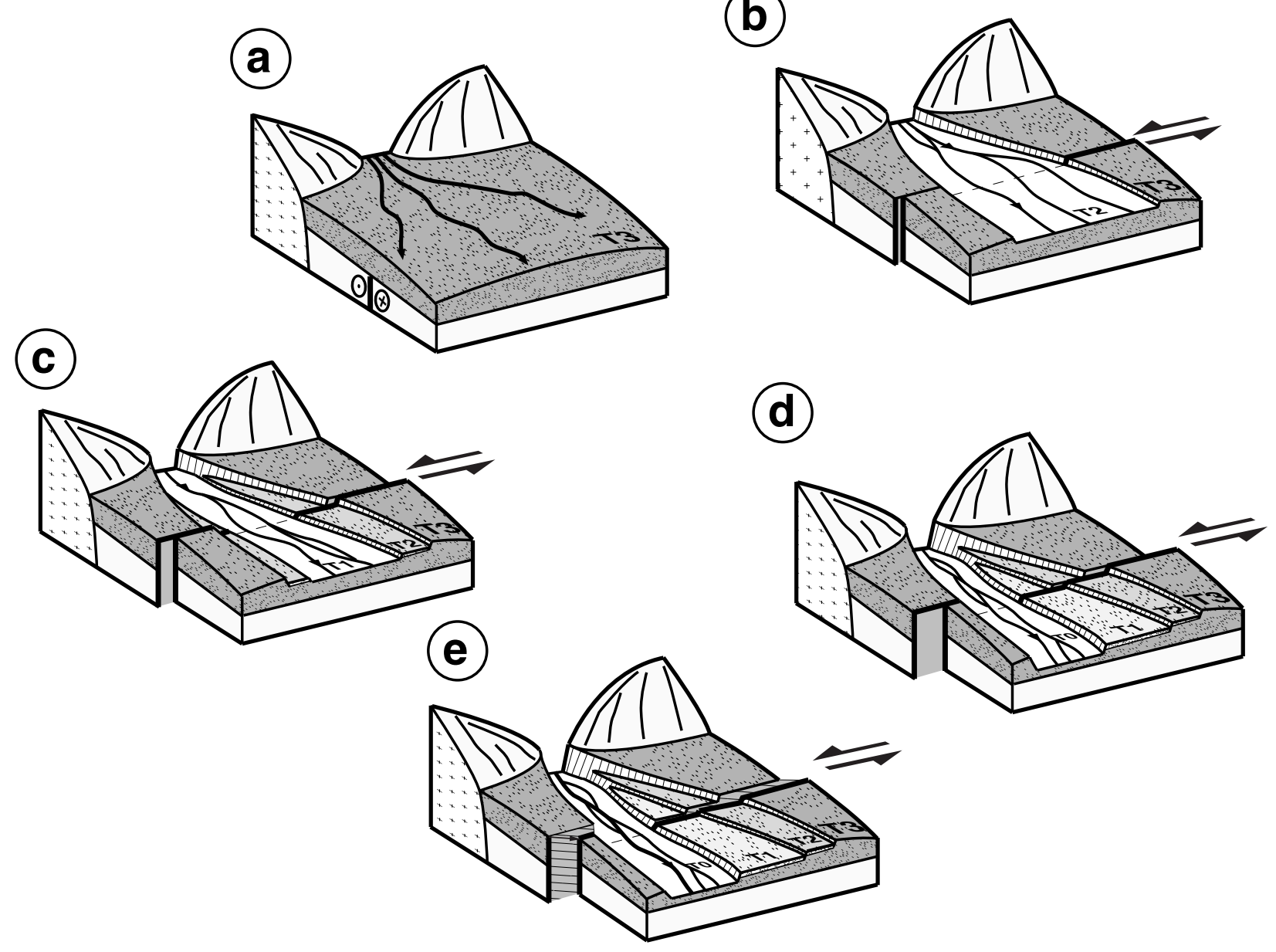

Figure 2. Ryerson et al. 


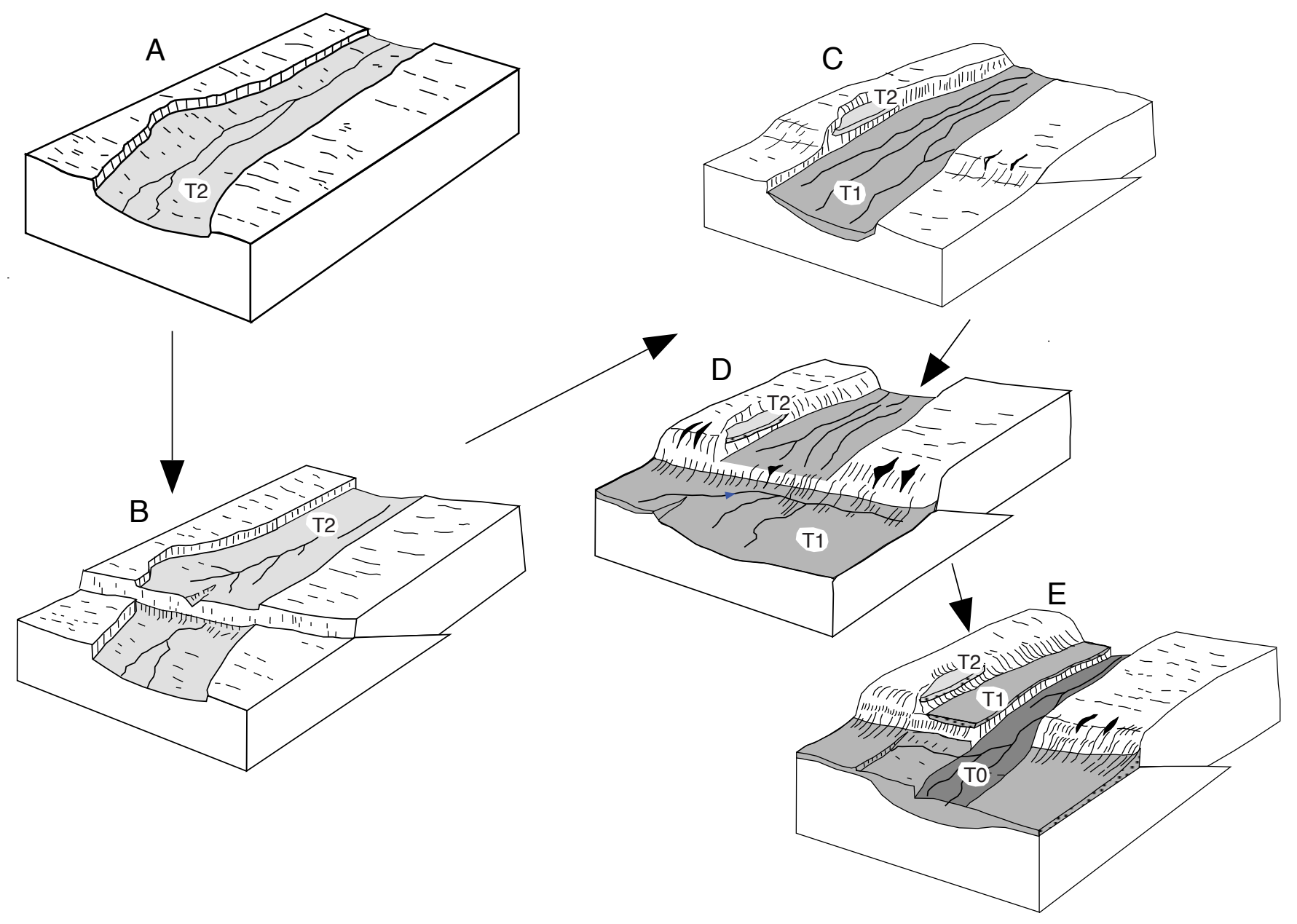

Figure 3. Ryerson et al. 


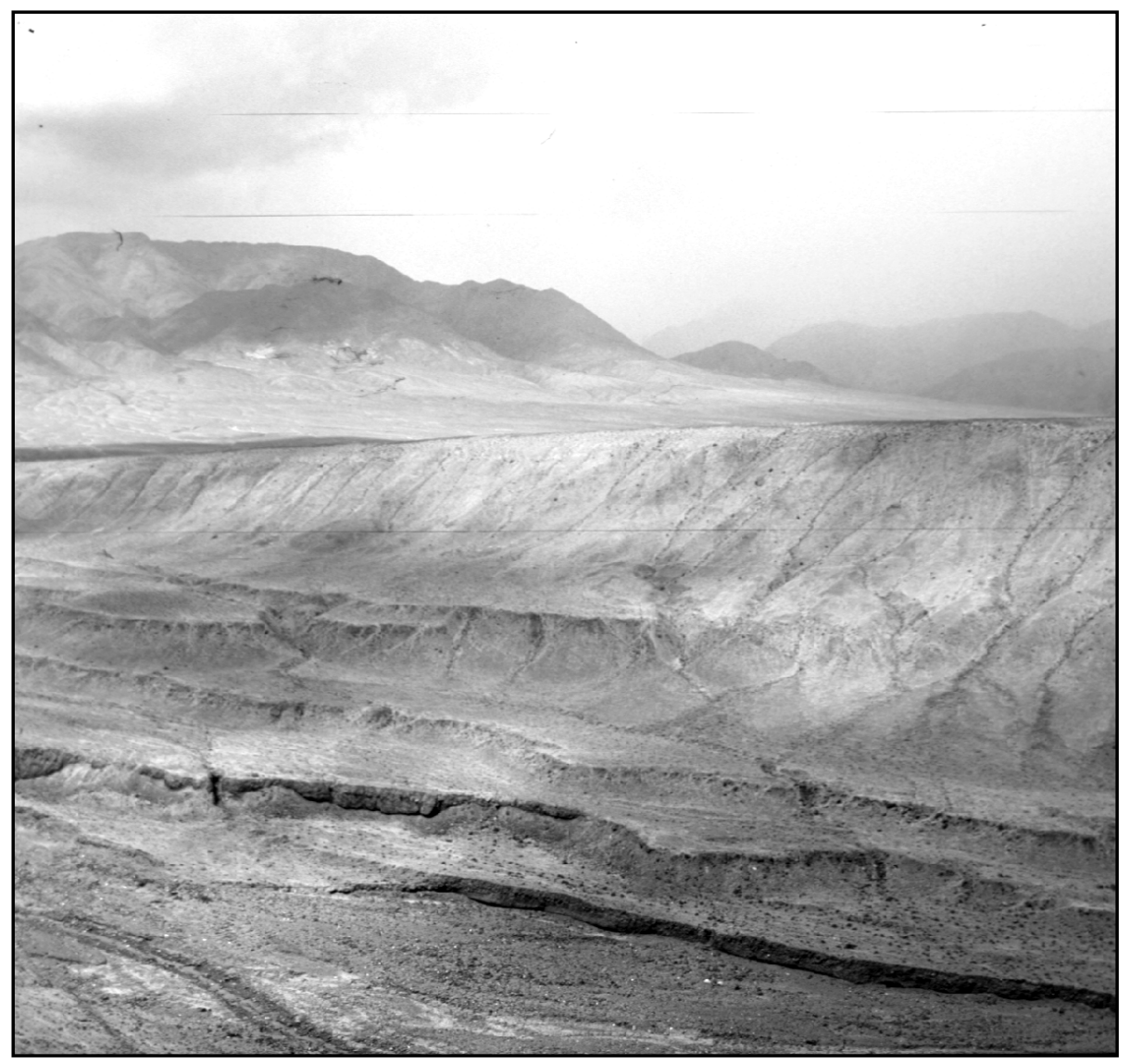

Figure 4. Ryerson et al. 


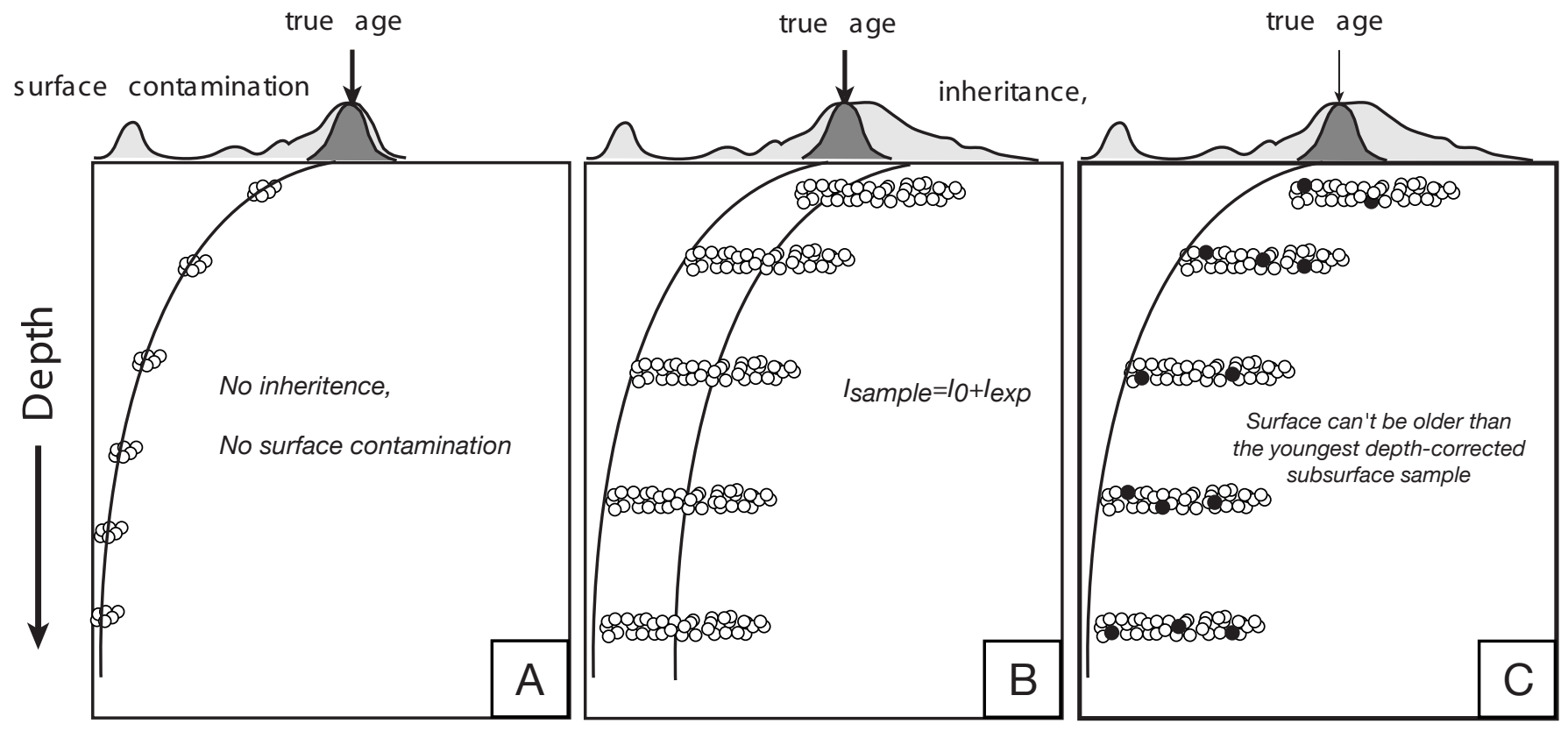

Nuclide concentration

Figure 5. Ryerson et al. 

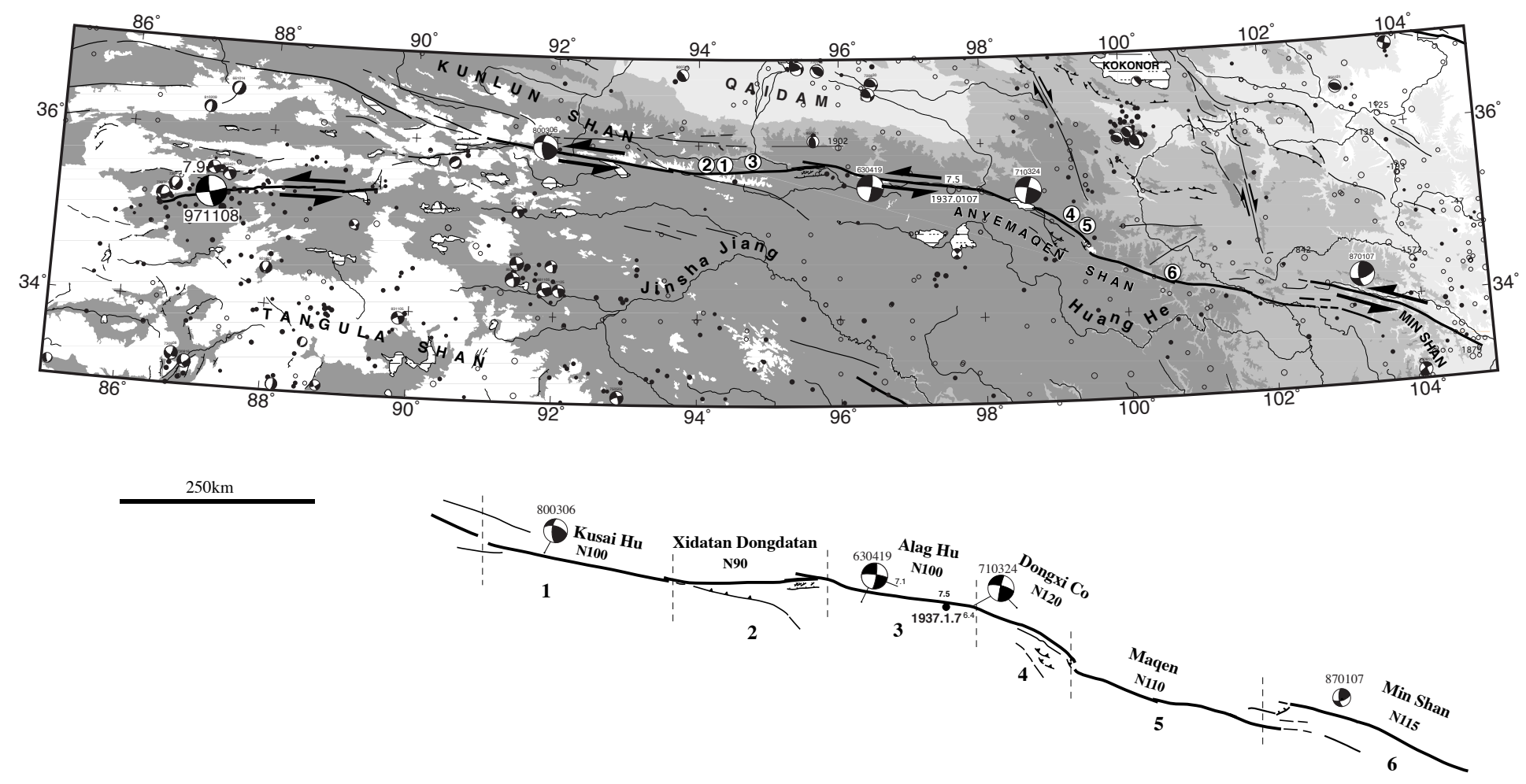

Figure 6. Ryerson et al. 


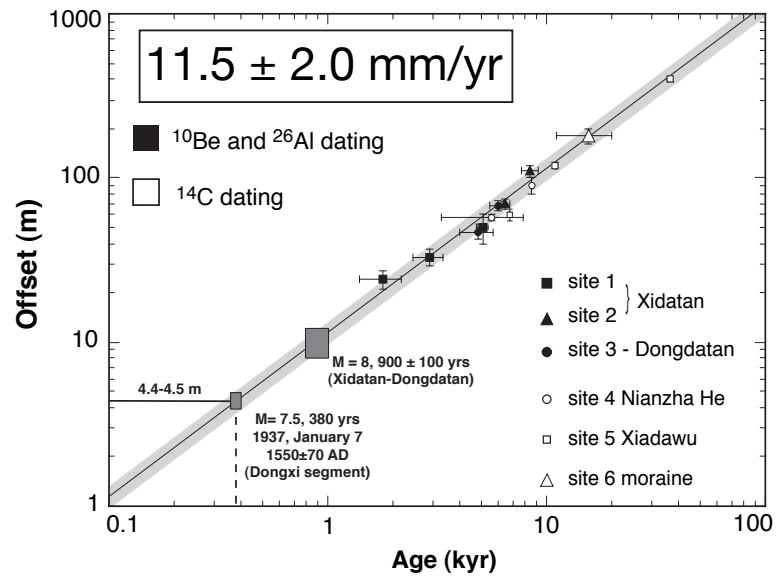

Figure 7. Ryerson et al 


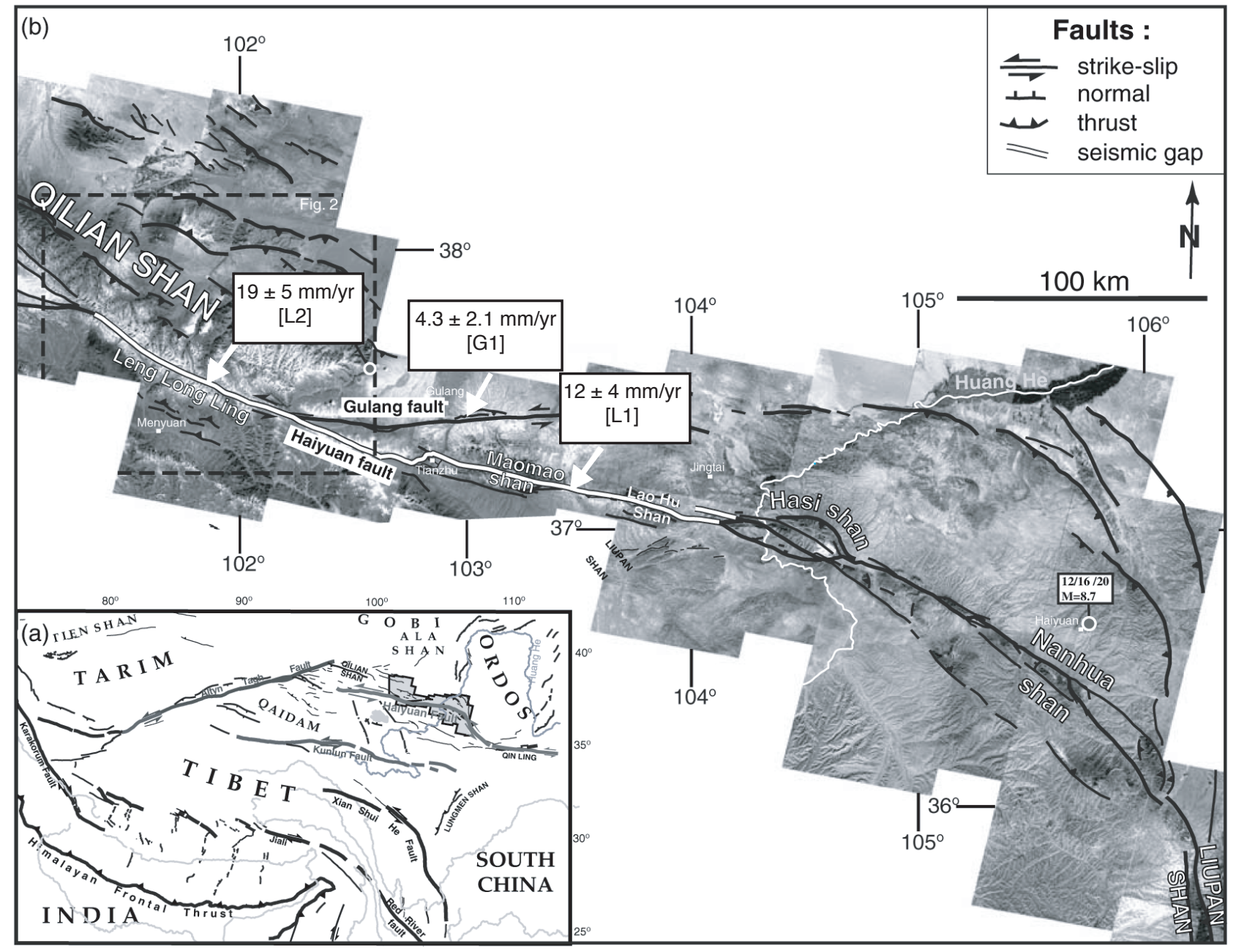

Figure 8, Ryerson et al. 


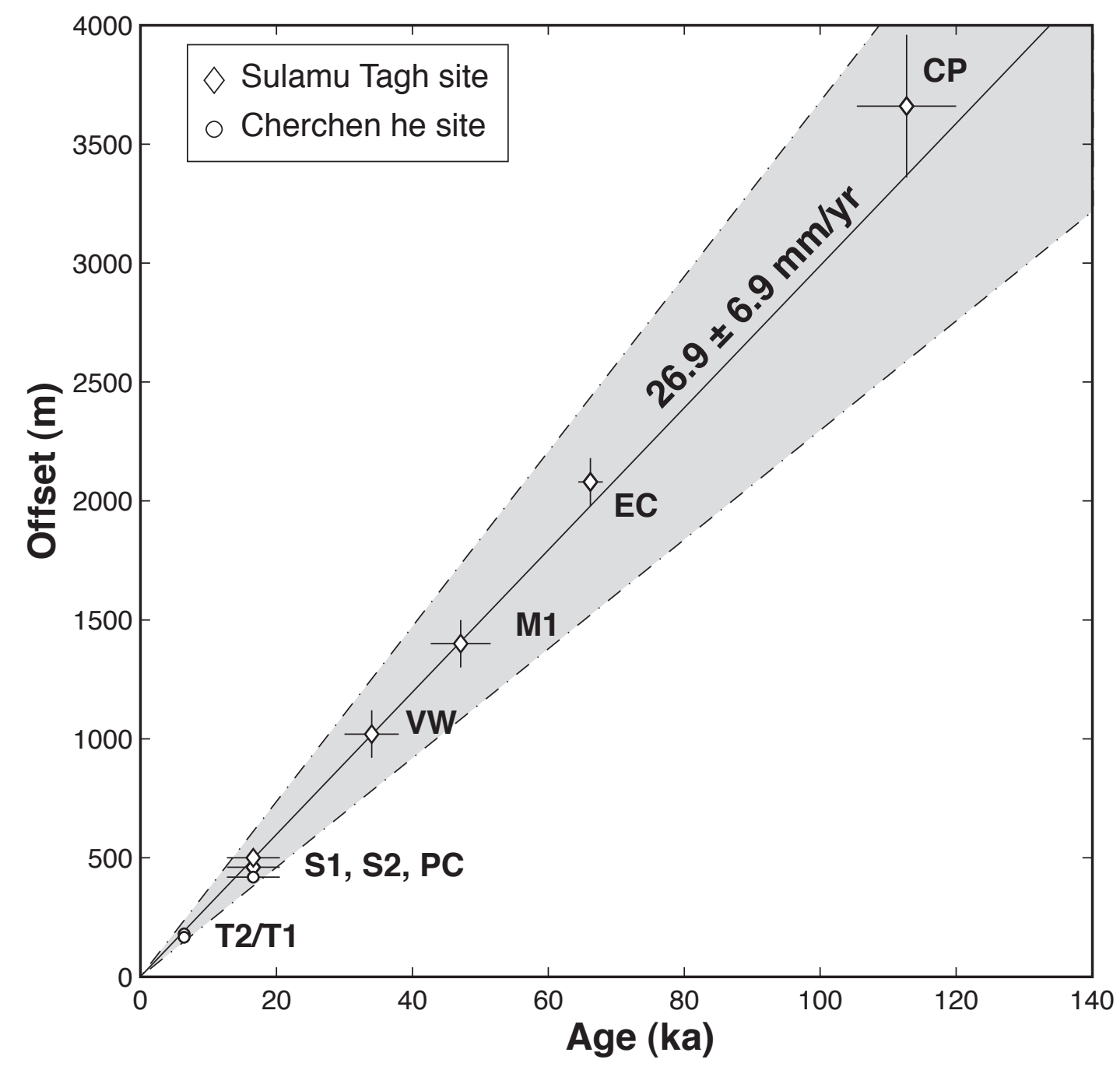

Figure 9. Ryerson et al. 

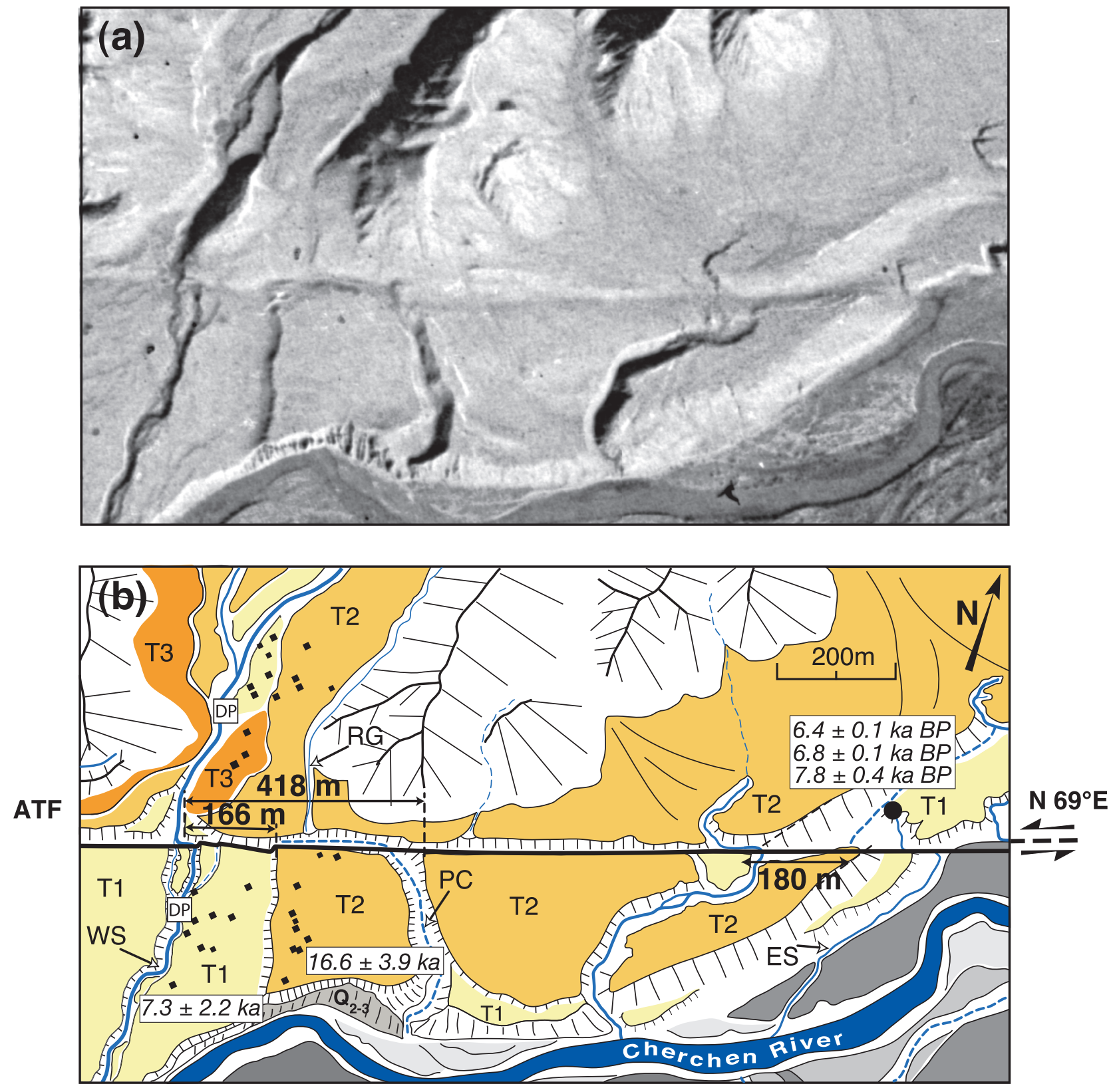

Figure 10, Ryerson et al. 


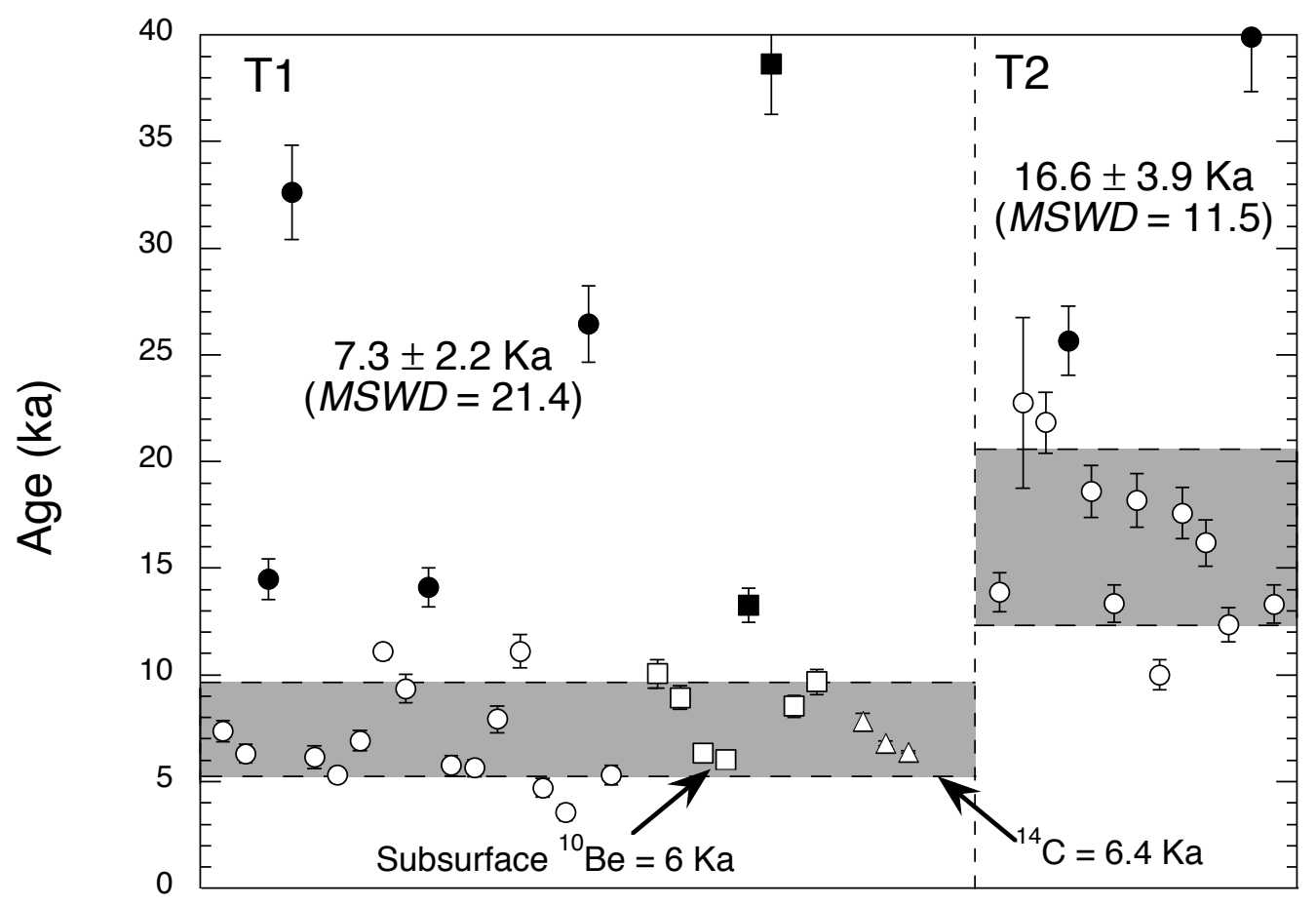

Figure 11, Ryerson et al. 


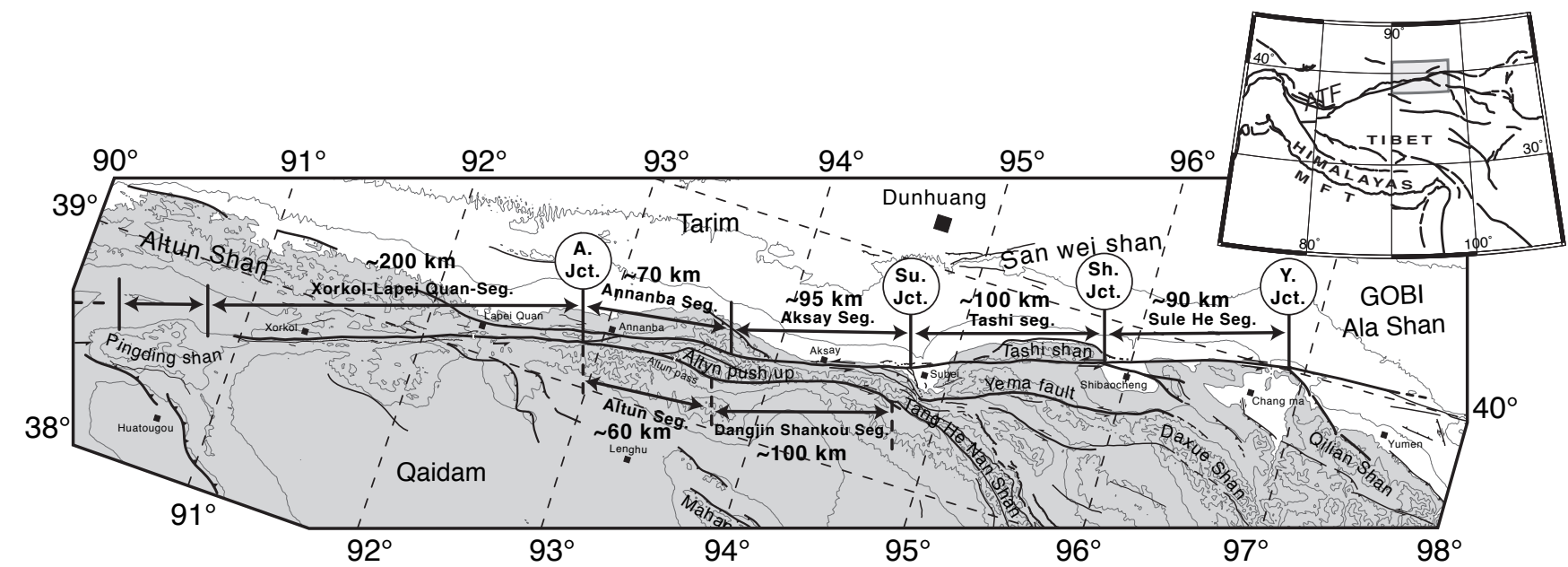

Figure 12. Ryerson et al. 


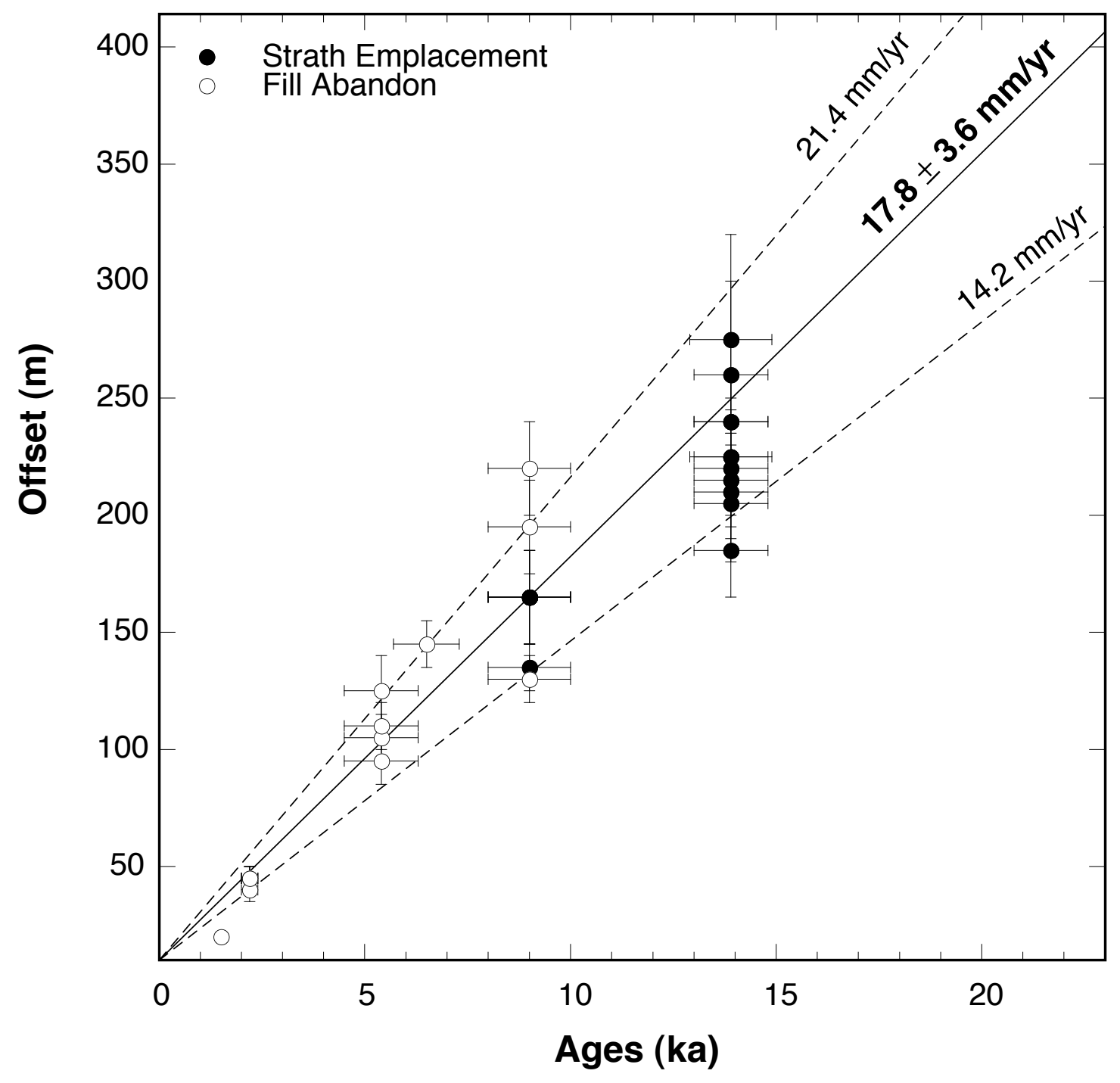

Figure 13. Ryerson et al. 

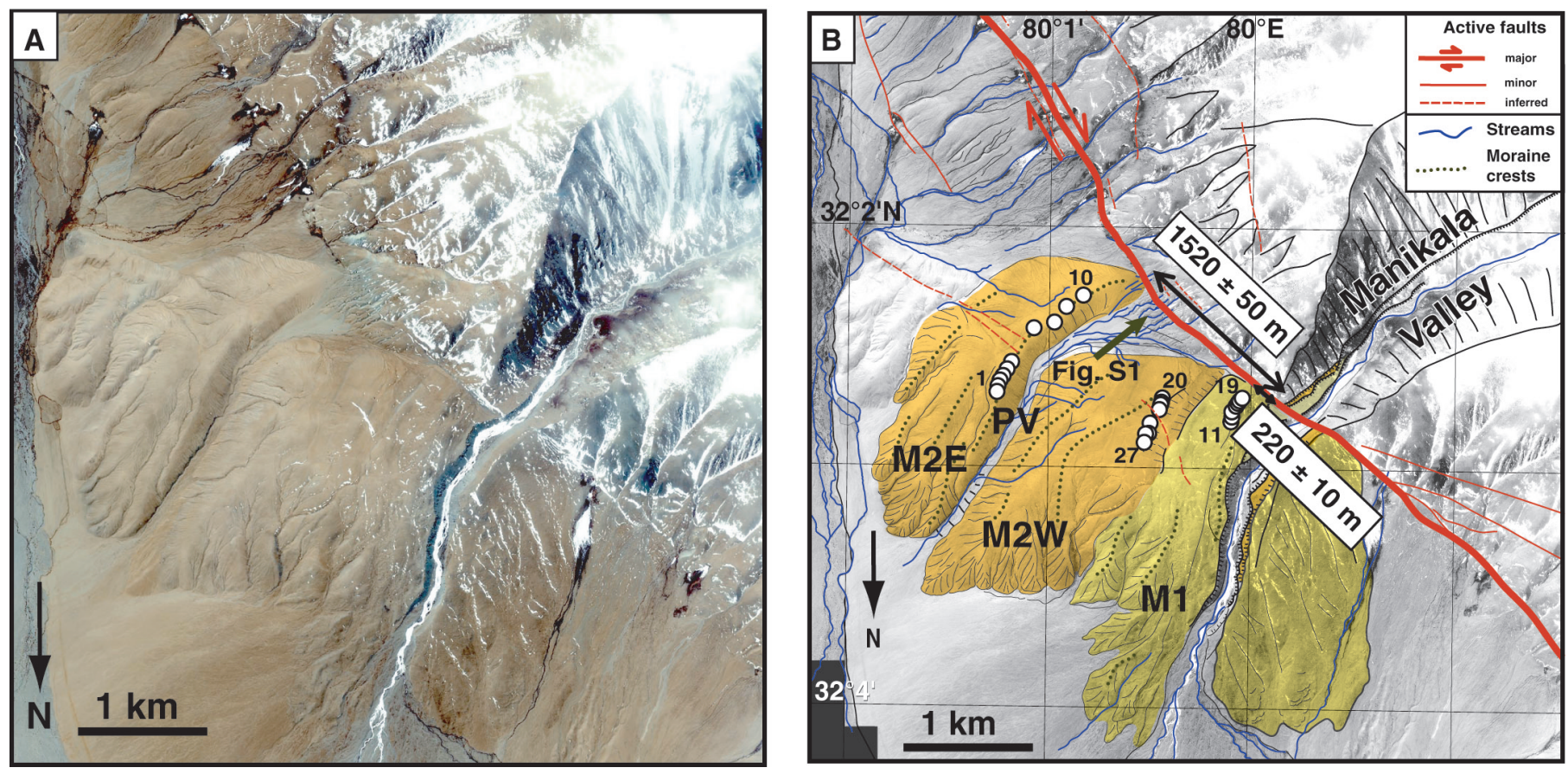

Figure 14. Ryerson et al. 

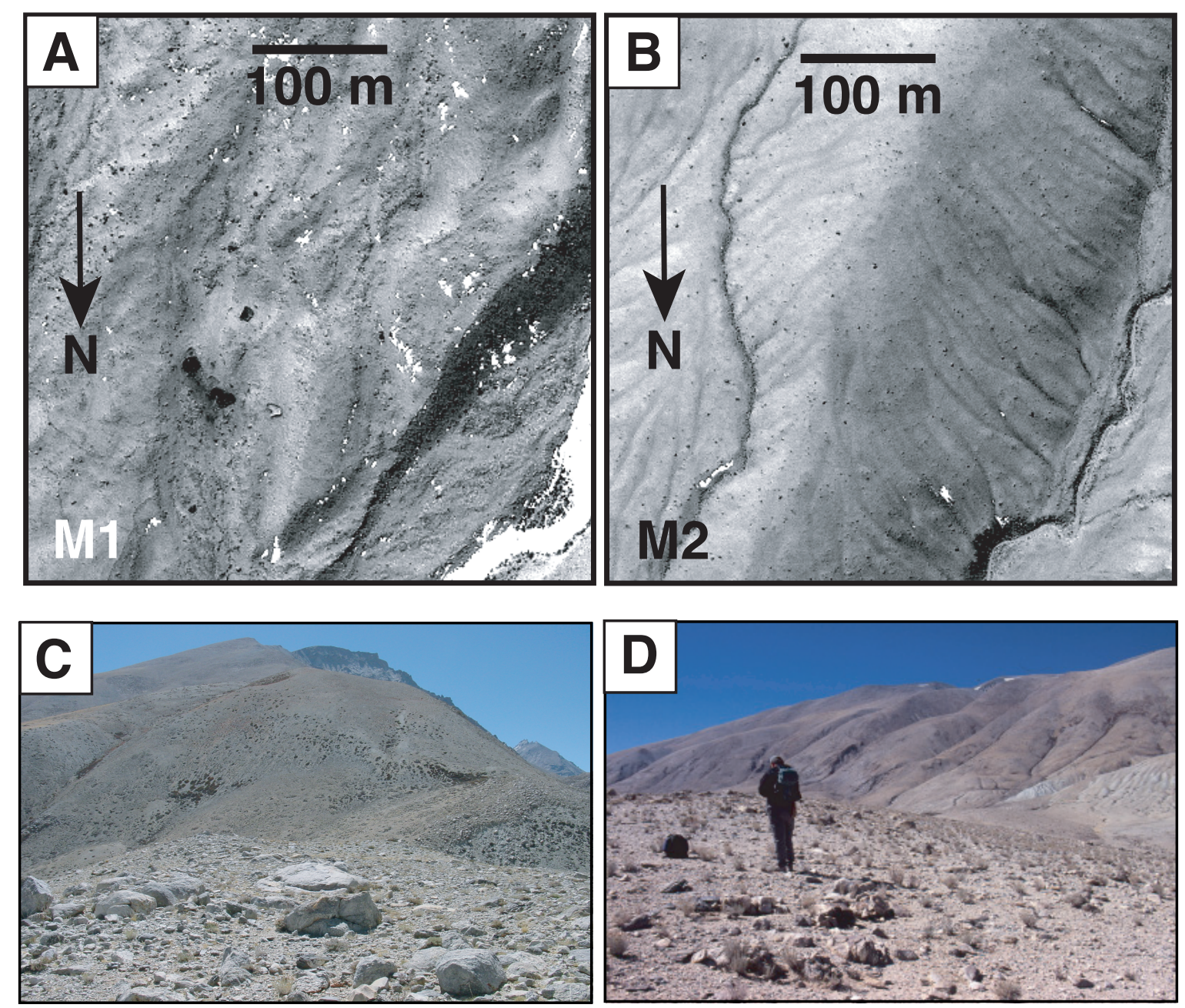

Figure 15, Ryerson et al. 


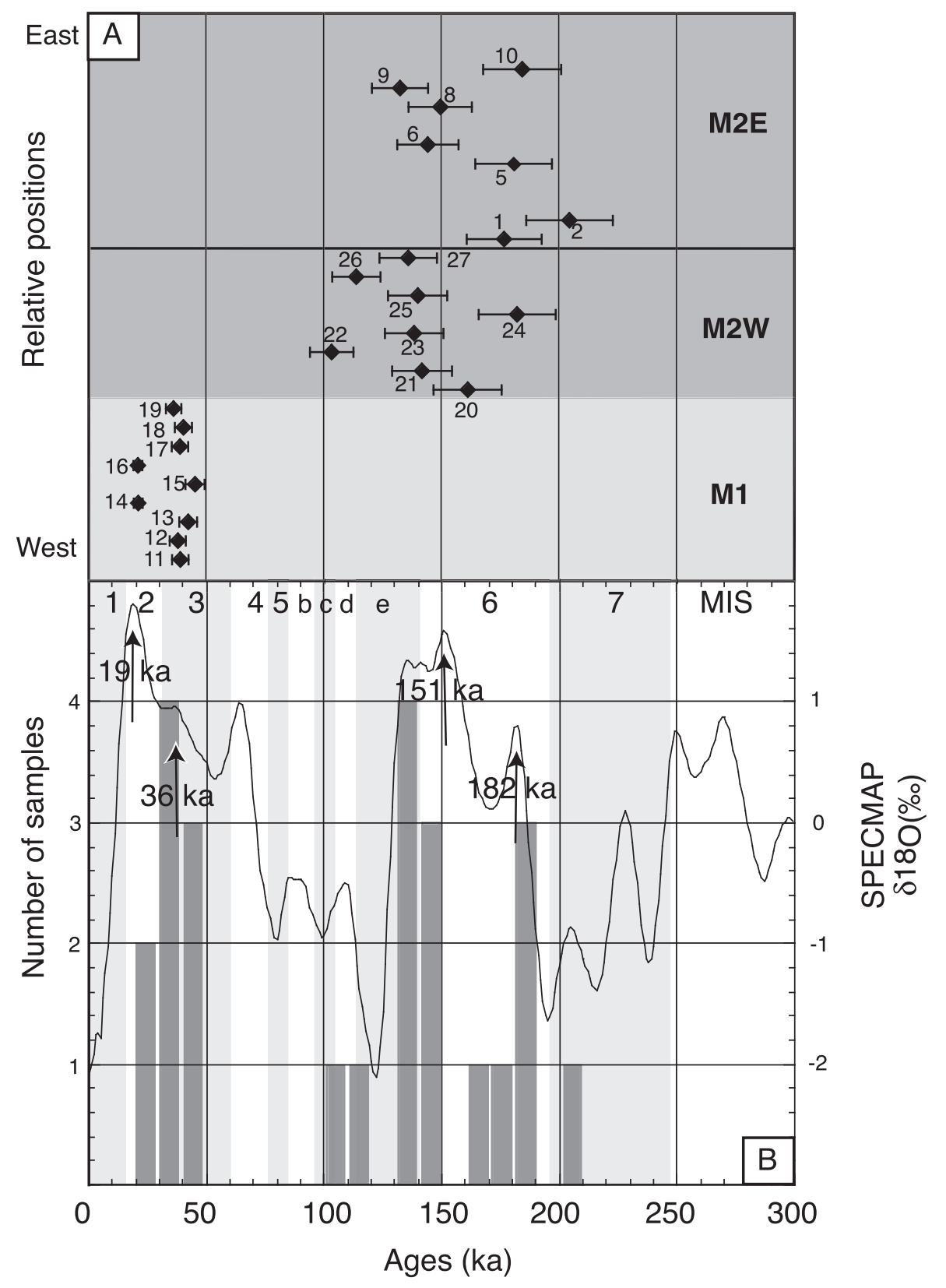

Figure 16, Ryerson et al. 


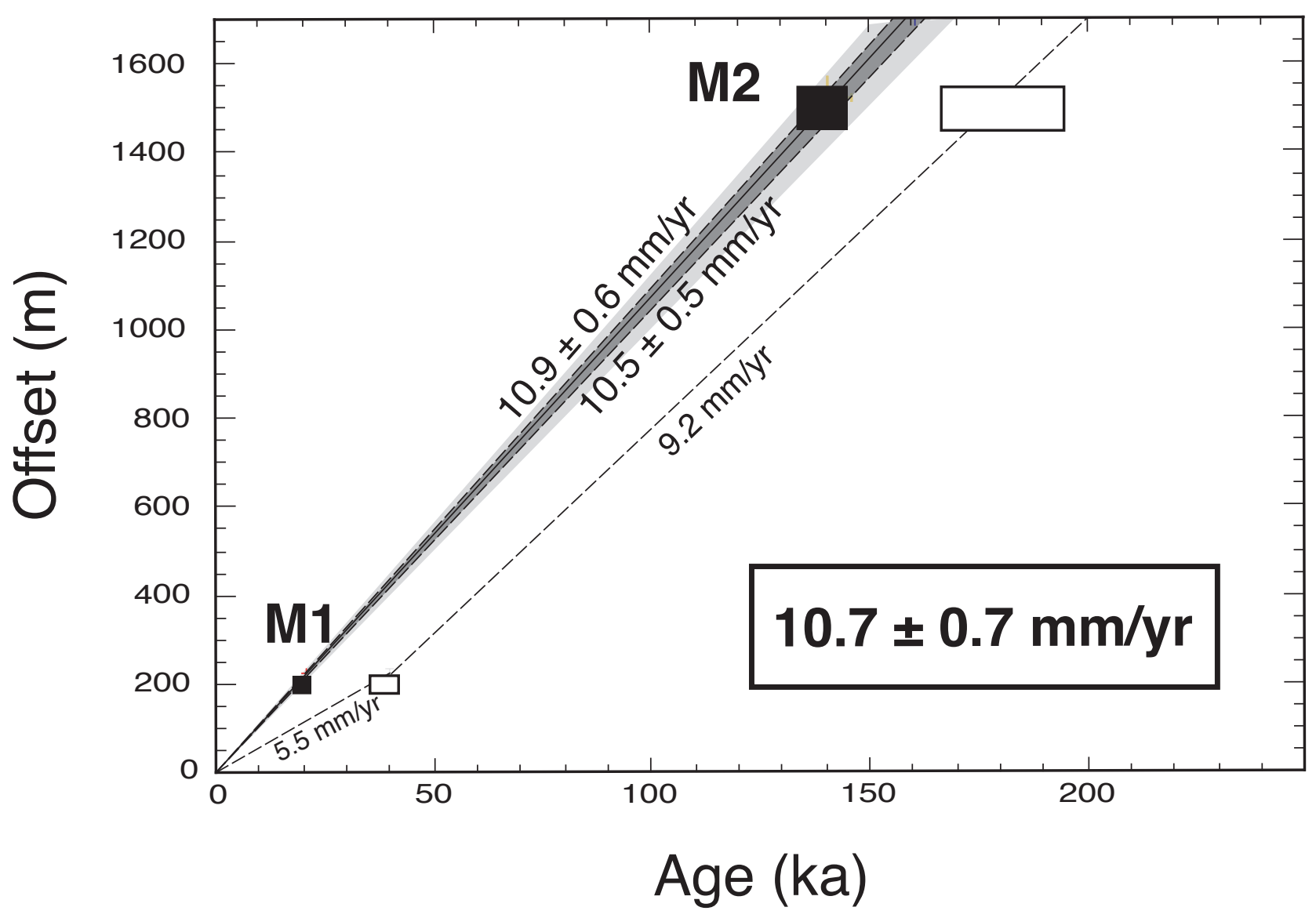

Figure 17, Ryerson et al. 


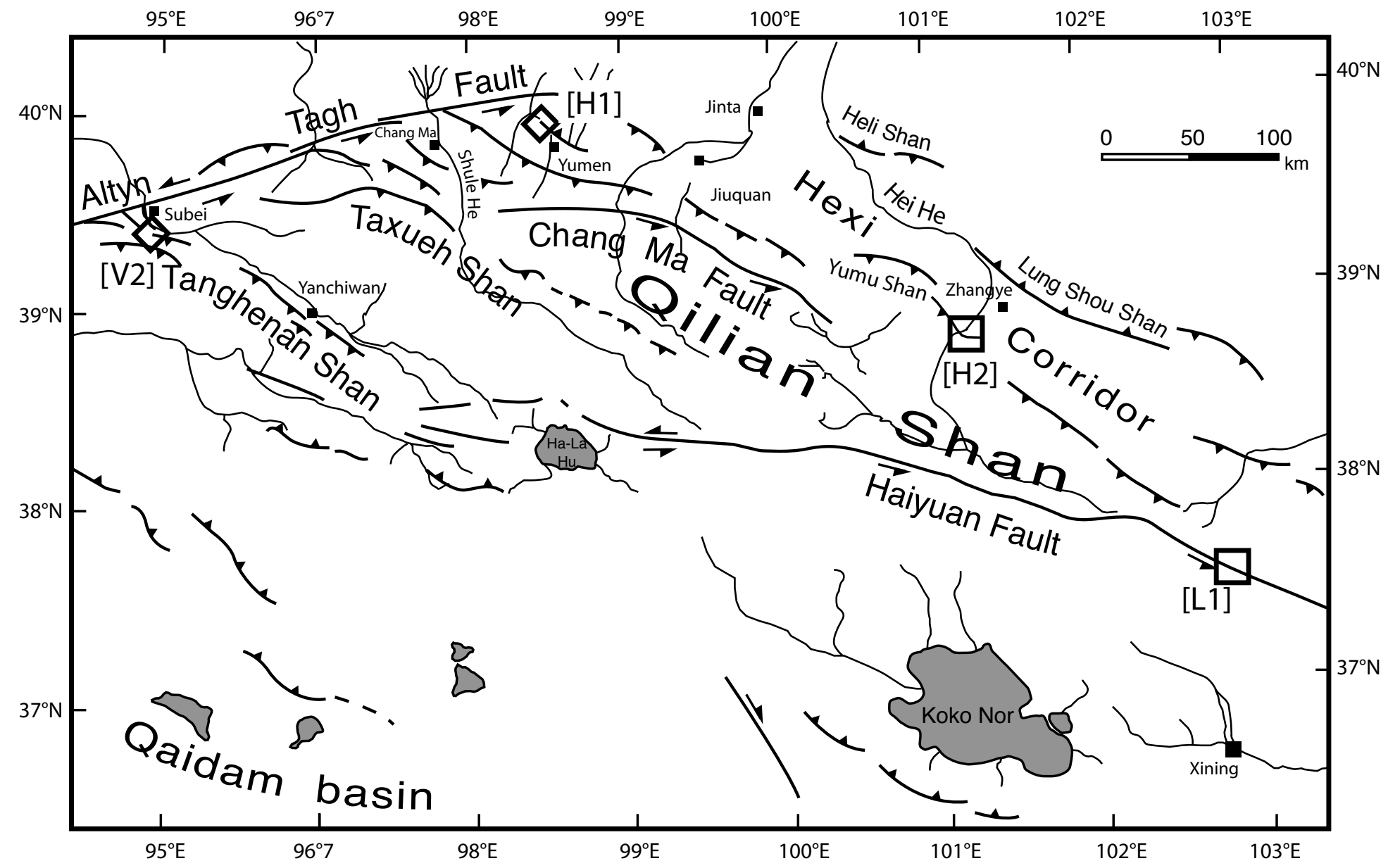

Figure 18. Ryerson et al. 


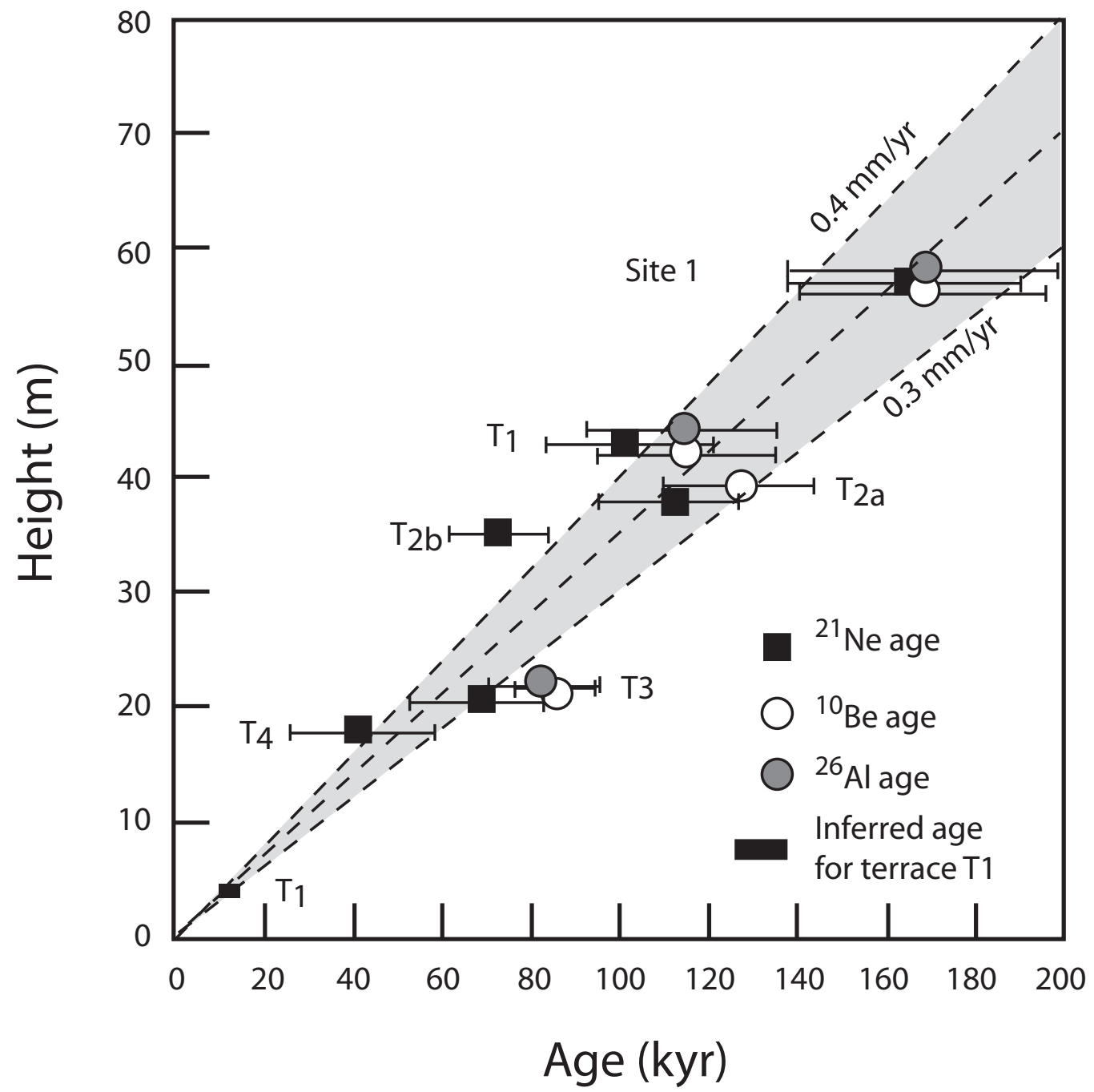

Figure 19. Ryerson et al. 


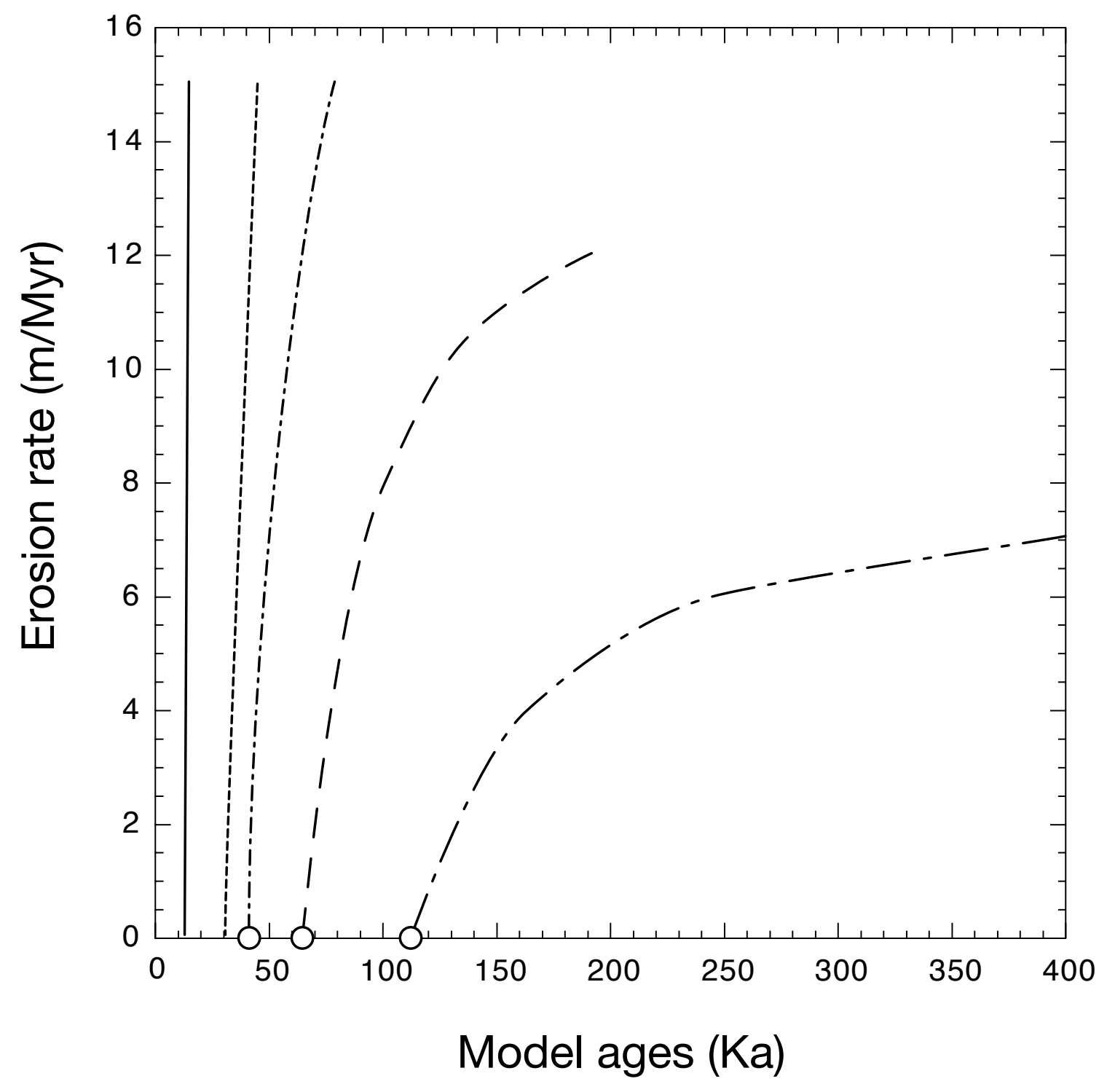

Figure 20, Ryerson et al. 


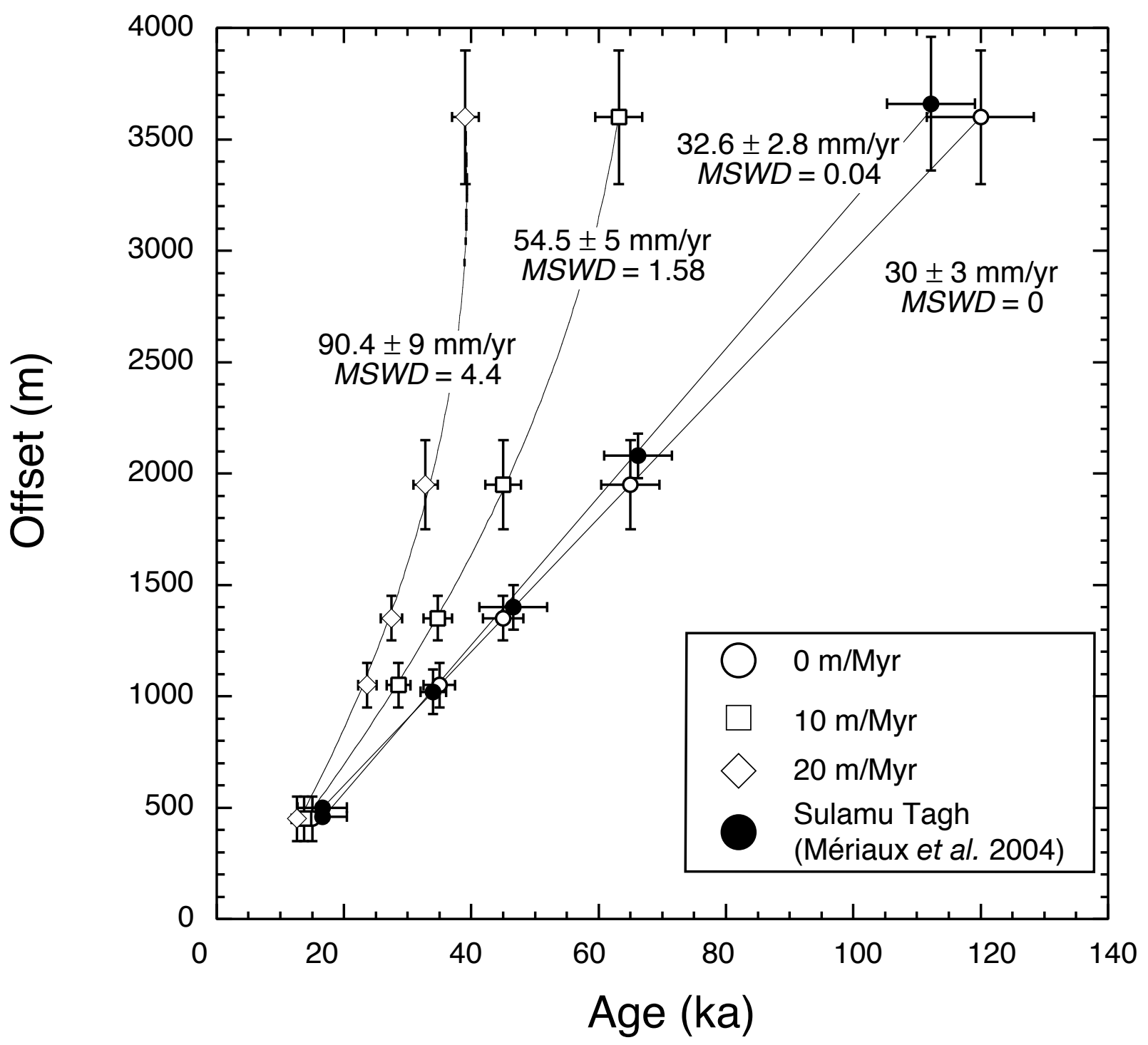

Figure 21. Ryerson et al 

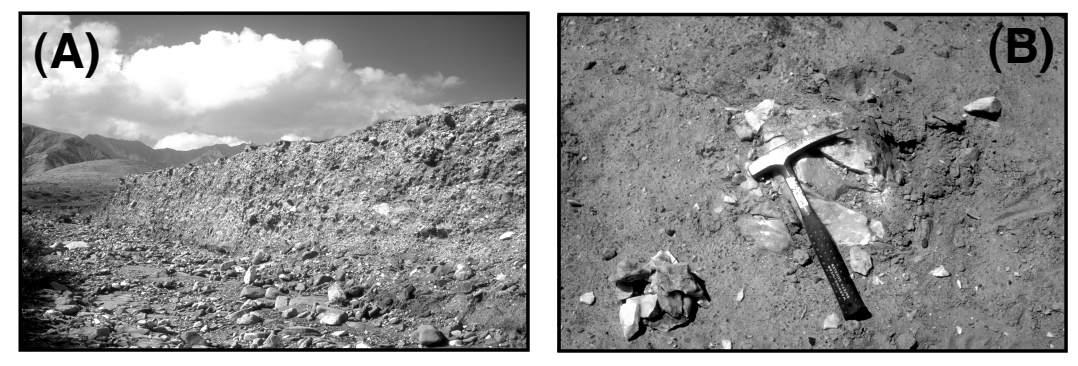

Figure 22, Ryerson et al. 